\title{
Medicinal Plants for Prophylaxis and Therapy of Common Infectious Diseases In Poultry-A Systematic Review of In Vivo Studies
}

\author{
Authors \\ Michael Walkenhorst ${ }^{2}$ \\ Affiliations \\ 1 Department of Clinical Research and Veterinary Public \\ Health, Division of Veterinary Pharmacology and \\ Toxicology, Vetsuisse Faculty, University of Bern, Bern, \\ Switzerland \\ 2 Department of Livestock Science, Research Institute of \\ Organic Agriculture (FiBL), Frick, Switzerland \\ 3 Department of Animal Science, Aarhus University, Aarhus, \\ Denmark \\ 4 Freie Universität Berlin, Institute of Pharmacy, Berlin, \\ Germany
}

Patricia Farinacci ${ }^{1,2}$, Meike Mevissen ${ }^{1}$, Hannah Ayrle ${ }^{2}$, Veronika Maurer ${ }^{2}$, Tina Sørensen Dalgaard ${ }^{3}$, Matthias F. Melzig ${ }^{4}$,

Key words

broiler, laying hen, bacterial infections, protozoal infections, phytotherapy, phytogenic feed additive, literature review, Origanum vulgare (Lamiaceae), Coriandrum sativum (Apiacea), Artemisia annua, Bidens pilosa (Asteraceae)

received

March 17, 2021

accepted after revision

June 29, 2021

published online

August 6, 2021

Bibliography

Planta Med 2022; 88: 200-217

DOI $10.1055 / \mathrm{a}-1543-5502$

ISSN 0032-0943

(c) 2021. Thieme. All rights reserved.

Georg Thieme Verlag KG, Rüdigerstraße 14,

70469 Stuttgart, Germany

Correspondence

Dr. med. vet. Michael Walkenhorst

Forschungsinstitut für biologischen Landbau (FiBL)

Ackerstrasse 113, 5070 Frick, Switzerland

Phone: +41 (0) 628657286 , Fax: + 41 (0) 628657273

michael.walkenhorst@fibl.org $\bigoplus \begin{aligned} & \text { Supplementary material is available under } \\ & \text { https://doi.org/10.1055/a-1543-5502 }\end{aligned}$

\section{ABSTRACT}

Medicinal plants for prophylaxis and therapy of common infectious diseases in poultry have been studied for several years. The goal of this review was to systematically identify plant species and evaluate their potential in prophylaxis and therapy of common diseases in poultry caused by bacteria and gastrointestinal protozoa. The procedure followed the recommendations of the PRISMA statement and the AMSTAR measurement tool. The PICOS scheme was used to design the research questions. Two databases were consulted, and publications were manually selected, according to predefined inand exclusion criteria. A scoring system was established to evaluate the remaining publications. Initially, 4197 identified publications were found, and 77 publications remained after manual sorting, including 38 publications with 70 experiments on bacterial infections and 39 publications with 78 experiments on gastrointestinal protozoa. In total, 83 plant species from 42 families were identified. Asteraceae and Lamiaceae were the most frequently found families with Artemisia annua being the most frequently found plant, followed by Origanum vulgare. As compared to placebo and positive or negative control groups, antimicrobial effects were found in 46 experiments, prebiotic effects in 19 experiments, and antiprotozoal effects in 47 experiments. In summary, a total of 274 positive effects predominated over 241 zero effects and 37 negative effects. Data indicate that $O$. vulgare, Coriandrum sativum, A. annua, and Bidens pilosa are promising plant species for prophylaxis and therapy of bacterial and protozoal diseases in poultry.

\section{Introduction}

Effective safeguarding of poultry health is essential to meet the demand for meat and eggs for human consumption [1]. High stocking density, growth, and laying performance as well as different infectious diseases like colibacillosis, salmonellosis, or coccidiosis are leading to an increase in morbidity and mortality in poultry of all ages. Hence, due to multifactorial circumstances, these infectious diseases create major economic losses [2]. It has been reported that the annual loss due to coccidiosis in poultry production was estimated up to 3 billion dollars worldwide $[3,4]$. The use of anticoccidial drugs as well as antimicrobials is still the most widespread measure to control coccidiosis and bacterial infections in poultry. In 2011, more than $40 \%$ of all antimicrobials 
sold in the UK for use in poultry were classified for the control of coccidian parasites, predominantly Eimeria [3]. In cattle and pigs, 20000 tons of antimicrobial each were used and for poultry the use of 8905 tons has been estimated in 31 countries in the EU in 2017 [5]. Besides pharmacotherapy, antibiotics were also used for prophylaxis and as a growth-promoting agent to increase productivity in livestock $[6,7]$. Use and misuse of antimicrobials may lead to the emergence of antimicrobial-resistant pathogens [6, 8]. In 2016, almost $70 \%$ of $E$. coli isolates from poultry from different EU countries showed antibiotic resistance against amoxicillin; in other countries like the USA, China, or Brazil, E. coli isolates showed resistances up to $100 \%$ against different antibiotic drugs [9]. A similar problem could be seen with the resistance against anticoccidial drugs: a study in China showed the development of various degrees of resistance of Eimeria spp. against most of the 8 anticoccidial drugs tested [7]. Resistance to the available chemicals has become widespread $[3,6,10]$. Due to the emergence of antimicrobial resistance, the EU Commission set a ban on antibiotics as growth promoters in animal feed in 2006, restricting the use of antibiotics to the sole purpose of veterinary treatment [11].

According to the sales data published from 2011 to 2017 by the European Surveillance of Veterinary Antimicrobial Consumption, a yearly decrease in sales of $32.5 \%$ was observed and the use of antibiotics decreased, and the list of highest critically important antibiotics showed fewer antimicrobials [5]. Anticoccidial drugs, however, are still allowed to be fed for prevention and growth promotor use.

In contrast to the amounts of antimicrobials used in poultry, the variety of antimicrobial veterinary medicinal products registered for use in poultry has decreased and is relatively small. In Switzerland, only 11 veterinary medicinal products against bacteria and coccidia are registered based on the official information system for Swiss veterinary medicinal products "CliniPharm" [12] for poultry. Seven of them are antibiotic drugs, with 4 belonging to the category "highest critically important antibiotic drugs".

The most important bacterial infections that were reported to lead to prominent economic losses in poultry production are salmonellosis, colibacillosis, and clostridiosis $[2,13]$. The pathophysiology of those infections is accompanied by several clinical symptoms like anorexia, apathy, diarrhea, reduced performance (egg production, daily weight gain, laying or feed conversion rate), or even mortality [14]. Similar problems can be observed on a global scale with protozoal infections like coccidiosis [13, 14]. Links between coccidiosis and increased colonization with pathogenic bacteria of the intestine have been described [3]. Coccidiosis is an infectious disease of the intestinal tract of wild and domestic animals caused by parasites of the phylum Apicomplexa. Especially Eimeria tenella remains highly invasive and is most likely the most important Eimeria species causing chicken coccidiosis [15]. The protozoal pathogens attach to intestinal epithelial cells, enter and replicate in the epithelial cell, leading to a rupture of the cells. This causes an interruption of food intake, dehydration, blood loss, increased mortality, poor growth, and reduced performance $[4,10,14]$. Therapeutic or prophylactic treatments of poultry diseases caused by bacterial and protozoal pathogens should have antibacterial, antiprotozoal, antidiarrheal, anti-inflammatory, antiadhesive, and analgesic properties ( $\bullet$ Table 1 ).

Numerous plant species were traditionally used by farmers in Europe for prophylaxis and therapy of poultry diseases. In Switzerland, 13 plant species were reported to be used by farmers [1620]. In a recent literature review about European ethnoveterinary practices, 63 plant species were documented for use in poultry in European countries [21], including the treatment of a variety of diseases like parasitosis and gastrointestinal diseases [17,21]. For the treatment of digestion problems and inflammation of the digestive tract, the use of a variety of medical plants has been described in recent German textbooks about veterinary herbal medicine [22,23]. Many herbs have been found efficacious in in vitro, in vivo, and/or clinical studies for the treatment of gastrointestinal diseases, and many different herbal compounds have been investigated for their potential use as a dietary supplement [10,24]. A recent systematic review on medicinal plants as a treatment option for gastrointestinal and respiratory livestock diseases showed that a high number of in vivo studies were performed on poultry [24].

The goal of this review was to systematically evaluate the current research on medicinal plants used in in vivo poultry studies in the context of the most important bacterial and protozoal infectious diseases and to identify the variety and potential of the different plant species studied. Previously published reviews mainly focused on "plant bioactives" or "phytogenics" to enhance productivity in poultry or to improve their performance [25-27], but a systematic analysis on disease control is lacking.

\section{Material and Methods}

The methods of this systematic review are based on the recommendations of the PRISMA statement $[28,29]$ and the AMSTAR measurement tool [30]. Moreover, they were performed following the design of a recently published study by Ayrle et al. [24]. The PICOS scheme [28] was used to design the research question: the population is poultry and included chickens, quails, turkey, and waterfowl, and the intervention is the administration or feeding of plant-based substances. The comparator is no treatment, placebo, or standard therapy (antibiotic or anticoccidial), and the outcomes are the effects on performance, health, bacteria, and gastrointestinal protozoa. The study design includes only in vivo or clinical studies with poultry and no in vitro studies. A detailed description of the study protocol is given in supplementary material file 1 .

\section{Selection of published scientific studies}

Literature search

The literature research was conducted in February 2018 by 1 person, and 2 databases, Web of Science [31] and PubMed [32], were consulted. No specific timeframe of publication years was considered. An additional literature search was done with the same databases for the period from February 2018 to February 2019 by 1 person. The search term in both databases consisted of the name of the animal species and the phytotherapeutic description: (layer* OR hens OR chicken* OR poultry OR fowl* OR duck* OR

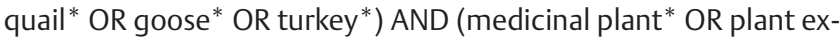


- Table 1 Challenging infectious diseases in poultry: pathogens, pathophysiology, and resulting demands for prophylaxis and therapy.

\begin{tabular}{|c|c|c|c|c|}
\hline \multicolumn{2}{|c|}{ Disease complex } & Pathogens & Pathophysiology (Pp) and clinical signs (Cs) & Demands for prophylaxis and therapy \\
\hline \multicolumn{5}{|l|}{ Bacteria } \\
\hline \multirow[t]{3}{*}{ Salmonellosis ${ }^{a}$} & $\begin{array}{l}\text { Paratyphoid } \\
\text { Sallmonellae }\end{array}$ & $\begin{array}{l}\text { S. enteritis, } \\
\text { S. typhimurium }\end{array}$ & $\begin{array}{l}\text { Pp: S. enteritis adheres to epithelial cells at the } \\
\text { tip of villi, toxin production } \rightarrow \text { changes density } \\
\text { and morphology } \rightarrow \text { electrolyte, intestinal fluid } \\
\text { are affected; septicemia. } \\
\text { Cs: embryo mortality, high mortality on hatch } \\
\text { day, rest similar to fowl typhoid and pullorum } \\
\text { disease. Adult animals are often symptomless. }\end{array}$ & \multirow[t]{3}{*}{$\begin{array}{l}\text { Anti-inflammatory, antiadhesive, analge- } \\
\text { sic, antidiarrheal, prebiotic, improved feed } \\
\text { intake, improved feed conversion rate, } \\
\text { anti-inflammatory, improved performance }\end{array}$} \\
\hline & Pullorum disease & S. pullorum & \multirow{2}{*}{$\begin{array}{l}\text { Pp: septicemia, focal necrotic lesions of mucosa, } \\
\text { liver, and spleens swollen, hemorrhagic streaks } \\
\text { Cs: weakness, anorexia, diarrhea, dehydration, } \\
\text { reduced growth, reduced feed intake, high } \\
\text { mortality, joint infections, blindness, reduced } \\
\text { fertility and hatchability, drop in egg production }\end{array}$} & \\
\hline & Fowl typhoid & S. gallinarum & & \\
\hline \multicolumn{2}{|c|}{ Necrtic enteritis/clostridiosis ${ }^{\mathrm{b}}$} & $\begin{array}{l}\text { Clostridium perfringes } \\
\text { Type A }\end{array}$ & $\begin{array}{l}\text { Pp: adheres to cell, toxin production, gross } \\
\text { lesions in the intestine } \\
\text { Cs: severe depression, anorexia, reluctance to } \\
\text { move, diarrhea and wet litter, ruffled feathers, } \\
\text { acute mortality, growth depression }\end{array}$ & $\begin{array}{l}\text { Antibacterial, analgesic, improved feed } \\
\text { intake, antiadhesive antidiarrheal, } \\
\text { prebiotic, spasmolytic, anti-inflammatory, } \\
\text { improved performance }\end{array}$ \\
\hline \multicolumn{2}{|l|}{ Colibacillosis ${ }^{c}$} & $\begin{array}{l}\text { avian pathogenic } \\
\text { Escherichia coli (APEC) } \\
\text { and enterotoxigenic } \\
\text { E. coli (ETEC) }\end{array}$ & $\begin{array}{l}\text { Pp: enters the host through mucosa or directly } \\
\text { through breaks in skin } \rightarrow \text { inflammation (serosi- } \\
\text { tis, cellulitis, enteritis, salpingitis, synovitis, } \\
\text { meningitis, etc.), dehydration, septicemia } \rightarrow \\
\text { synovitis and osteomyelitis } \\
\text { Cs: depression, fever, diarrhea, reduced egg } \\
\text { production, high mortality }\end{array}$ & $\begin{array}{l}\text { Antibacterial, anti-inflammatory, } \\
\text { analgesic, immunostimulatory, } \\
\text { antidiarrheal, improved performance }\end{array}$ \\
\hline \multicolumn{2}{|c|}{ Campylobacteriosis $^{\mathrm{d}}$} & Campylobacter jejuni & $\begin{array}{l}\text { Rare/no obvious clinical signs in poultry but in } \\
\text { humans }\end{array}$ & \\
\hline \multicolumn{5}{|c|}{ Gastrointestinal Protozoa } \\
\hline \multicolumn{2}{|l|}{ Coccidiosise $^{\mathrm{e}}$} & $\begin{array}{l}\text { Eimeria spp. (E. acer- } \\
\text { vulina, E. brunetti, } \\
\text { E. maxima, Eimeria } \\
\text { mitis E. necratix, } \\
\text { E. praecox, E. tenella) }\end{array}$ & $\begin{array}{l}\text { Pp: E. adheres to epithelial cells in the intestine, } \\
\text { replications intracellular in intestine } \rightarrow \text { rupture } \\
\text { of epithelial cell wall } \rightarrow \text { tissue damage, dehy- } \\
\text { dration, blood loss, increased intestinal passage } \\
\text { time, intestinal malabsorption, reduced } \\
\text { nutrient digestion, villous atrophy, intestinal } \\
\text { leakage of plasma proteins, increased intestine } \\
\text { activity } \\
\text { Cs: reduced weight gain, reduced feed conver- } \\
\text { sion efficiency, reduced feed and water intake, } \\
\text { bloody diarrhea, decreased digesta viscosity }\end{array}$ & $\begin{array}{l}\text { Antiadhesive, antiprotozoal, spasmolytic, } \\
\text { improved feed intake, improved feed } \\
\text { conversion rate, improved weight gain, } \\
\text { anti-inflammatory }\end{array}$ \\
\hline \multicolumn{2}{|l|}{ Histomonosis ${ }^{f}$} & Histomonas meleagridis & $\begin{array}{l}\text { Pp: ulceration and inflammation of cecal walls, } \\
\text { inflammation of mesenteric, necrosis of the } \\
\text { liver, engorgement of the ceca } \\
\text { Cs: yellow feces, drowsiness, anorexia, cyanotic } \\
\text { head, increased mortality }\end{array}$ & $\begin{array}{l}\text { Antiprotozoal, anti-inflammatory, } \\
\text { improved blood circulation, prokinetic, } \\
\text { prebiotic }\end{array}$ \\
\hline
\end{tabular}

tract OR phytogenic feed additive OR herbal OR phytotherapy). In the Web of Science keyword search, the results were refined with the categories "agriculture" or "veterinary science" and only in the languages "English", "German”, or "French". In the PubMed keyword research, the results were refined with "other animals", "language" (only in English, French, or German language), “complementary medicine”, "dietary supplements", "history of medicine”, "systematic reviews", "toxicology and veterinary science”, and an additional MeshTerm search was conducted with the terms "phytotherapy", "poultry", and "plant extracts".

\section{Manual sorting of experiments according to predetermined criteria}

After the removal of duplicates, the remaining publications were refined manually by selective screening of the title and the abstract by 2 evaluators. Publications were maintained if they fit 
- Table 2 Schematic representation of the scoring system used in the systematic literature search for each parameter measured in each experiment.

\begin{tabular}{|c|c|c|c|}
\hline Effects* & Score definition & $\begin{array}{l}\text { Experiments that compared a medicinal } \\
\text { plant-based treatment only with an } \\
\text { antiparasitic, antibacterial, or another } \\
\text { treatment** as control. }^{*} \text {. }\end{array}$ & $\begin{array}{l}\text { Experiments that compared a medicinal } \\
\text { plant-based treatment at least with a } \\
\text { negative control group (placebo treatment } \\
\text { or no treatment), sometimes, in addition, } \\
\text { with an antiparasitic, antibacterial, } \\
\text { or another treatment }{ }^{* * *} \text { as control. }\end{array}$ \\
\hline+ & $\begin{array}{l}\text { The positive effect (in the case of several } \\
\text { dosages of } 1 \text { plant material at least } 1 \text { dosage } \\
\text { showed a positive effect and other dosages } \\
\text { showed no effect). }\end{array}$ & $\begin{array}{l}\text { Medicinal plant-based treatment showed a } \\
\text { significant positive effect or no difference } \\
\text { compared to the control. }\end{array}$ & $\begin{array}{l}\text { Medicinal plant-based treatment showed a } \\
\text { significant positive effect compared to the } \\
\text { negative control. }\end{array}$ \\
\hline 0 & No effect & $\begin{array}{l}\text { Medicinal plant-based treatment showed a } \\
\text { significant negative difference compared to } \\
\text { the control. }\end{array}$ & $\begin{array}{l}\text { Medicinal plant-based treatment showed } \\
\text { no significant difference from the negative } \\
\text { control. }\end{array}$ \\
\hline- & $\begin{array}{l}\text { The negative effect (in case of several dos- } \\
\text { ages of } 1 \text { plant material at least } 1 \text { dosage } \\
\text { showed a negative effect and other dosages } \\
\text { showed no effect) }\end{array}$ & $\begin{array}{l}\text { (In this experimental design, it is not possible } \\
\text { to distinguish between a lack of effect and a } \\
\text { negative effect.) }\end{array}$ & $\begin{array}{l}\text { Medicinal plant-based treatment showed a } \\
\text { significant negative effect compared to the } \\
\text { negative control. }\end{array}$ \\
\hline$n$ & \multicolumn{3}{|l|}{ No data available } \\
\hline$?$ & \multicolumn{3}{|c|}{$\begin{array}{l}\text { In the case of experiments with several dosages of } 1 \text { plant material: if at least } 1 \text { dosage showed a positive and another dosage a negative effect } \\
\text { compared to the negative control group. }\end{array}$} \\
\hline
\end{tabular}

the predefined inclusion criteria and were sorted according to pathogen-associated categories in an Endnote database.

\section{Inclusion and exclusion criteria}

To be included, publications had to provide an abstract written in English, French, or German. Further, the publications had to include an assessment of oral administration (via feed or drinking water) of plant-based materials in an in vivo trial with poultry. In addition, in these trials, a challenge of the poultry with bacteria and/or gastrointestinal protozoa must have been conducted, or a detailed description of the intestinal microflora must have been included. Effects of the medicinal plant-based treatment (e.g., antidiarrheic effects, immunotropic effects, anti-inflammatory effects, antioxidant effects, improved growth, improved feed conversion rate, etc.) must have been described. In addition, a control group (placebo, untreated, and/or positive control groups like antibiotics or anticoccidials) had to be included. Publications without an abstract investigating a mixture of different plant species in a combined preparation or publications that did not distinguish the plant species or did not mention the Latin name of the plant used were excluded. Furthermore, publications reporting studies on vinegar, charcoal, soil, prebiotics, yeast, other animals than chickens, quails, turkeys, or waterfowl; studies with eggs or embryos; studies focusing only on feed, performance, or product quality; and studies on synthetic single substances were also excluded. Publications that fulfilled the inclusion criteria but where no full text was available were excluded.

\section{Classification}

The included publications were divided into 2 main groups: "bacteria" and "gastrointestinal protozoa". Before adding the respective information of the included publications in a table, a distinction between "publication" (as one scientific paper) and "experiment" was made, based on the fact, that some publications included several trials or trials with more than 1 medicinal plant. Other publications referred to more than 1 animal species (e.g., Artemisia annua L. tested in turkeys and chickens). Therefore, the following definition of "experiment" was used: Experiment = plant species $\times$ animal species $\times$ trial $\times$ publication. Hence, as an example, a publication referring to 2 controlled trials with 2 animal species ( 1 with quails and 1 with chickens) and 2 plant species each ( 3 groups in each trial: 1 with peppermint, 1 with garlic, and 1 control group) would lead to 4 "experiments": garlic $\times$ chicken, peppermint $\times$ chicken, garlic $\times$ quails, and peppermint $\times$ quails.

\section{Assessment}

All experiments were evaluated according to the following characteristics: plant species, plant family, a pharmaceutical form of the plant (extract), dosage/concentration, trial specification (on a station/on a farm), poultry species, age of the poultry at the start of the trial, number ( $n$ ) of individuals per group, distribution of animals to different treatment groups (randomized or not), comparator, issue of the study, way of application, duration of administration, and observation period (from the first day of application) and were entered in a data table (Table 1S, Supporting Information). To determine the recent bionomical nomenclature of the plant species used in the trials, the web page "the plant list" [33] 
was used. The potential of the plant species was evaluated based on possible effects, improving the expected pathophysiology of the most common, and important bacterial and protozoal infectious diseases in poultry ( $\vee$ Table 1 ). The plant-based treatment was screened for the following effects: antibacterial, synergism with antibiotics, antiprotozoal, antiadhesive, antidiarrheic, gut spasmolytic, lung spasmolytic, expectorant (secretolytic/mucolytic/secretomotoric), antitussive, anti-inflammatory, analgesic, antioxidant, immunotropic/stimulation of immune system, intestinal microbiota (prebiotic; predominantly assessed based on the lactobacillus population), improved growth, improved feed intake, improved feed conversion rate, improved egg production or other effects.

\section{Scoring System}

A scoring system was established for each parameter to estimate the plants' potential for prophylaxis or therapy ( $\bullet$ Table 2 ). The following system was, for example, used for studies with a negative control: if an experiment showed a significant positive effect of a plant-based substance compared to placebo or no treatment (in several dosages or at least in 1 dosage and no dosage showed a negative effect), it was marked as a "+" in the respective data table. If the plant-based substance showed no significant difference, it was marked as " 0 ". In case the plant-based substance showed a significant negative effect (in several dosages or at least in 1 dosage, and no dosage showed a positive effect), it was marked as a "-". A "?" was given if the experiment used different dosages, and at least 1 dosage showed a positive and another dosage a negative effect. The same procedure was used if different durations of administrations had been compared within 1 experiment. An " $n$ " was given if there were no data available on the specific parameter. For plant species with reports from 2 or more experiments, a total score for each "+", " 0 ", and "-" as well as a total summation (counting "+" as 1 , “ 0 ” as 0 , and "-" as - 1 ) was calculated.

\section{Results}

Database screening resulted in 4197 hits, and 3345 publications remained after the removal of 852 duplicates. After screening the titles of the publications, 3068 publications were excluded because they did not match the defined criteria, and finally a total of 277 publications remained. Out of these, 197 studies were excluded after screening the abstracts of the publications for the defined criteria. Sometimes, as examples, only growth-promoting factors were studied, without a link to bacterial or gastrointestinal protozoal infection, or a mixture of plant species was used in the trial, or no Latin name of the used plant species was given. The remaining 80 publications resulted in 77 included publications, due to lack of full-text availability or language issues in the remaining 3 ( $\triangleright$ Fig. 1). These publications were published between 1997 and 2019 and described 148 experiments (Table 1S, Supporting Information).

More publications were found between the years 2011 and 2016 compared to the time period ranging from 1997 to 2010. After 2016, the number of publications obtained decreased again ( $\triangleright$ Fig. 2).

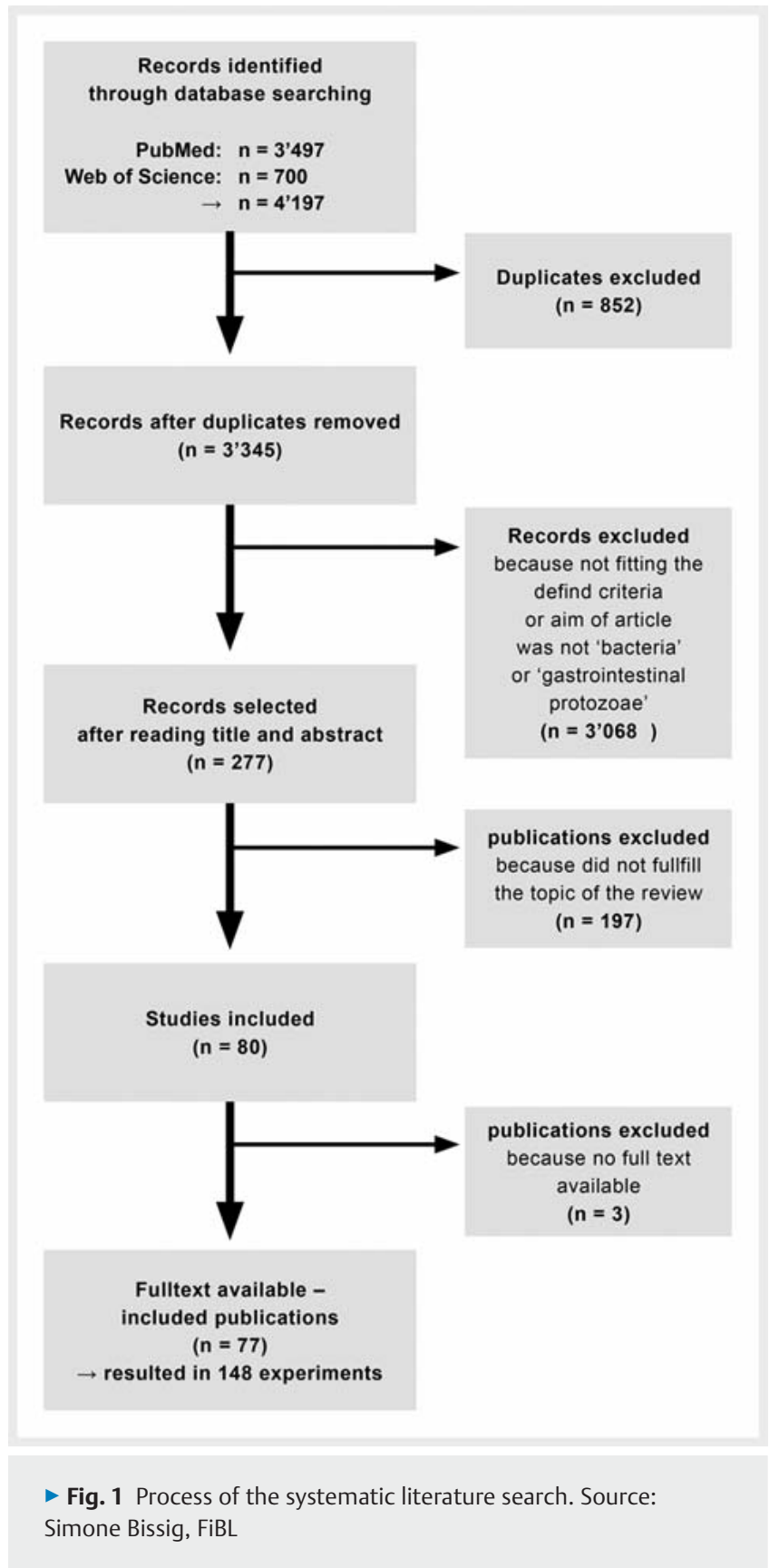

Publications were divided into 2 groups, namely "bacterial" and "gastrointestinal protozoal" infections: 38 publications, focusing on "bacteria", comprised 70 experiments, wherein 5 focused on "campylobacter species", 4 on "clostridia species", 16 on "E. coli", 5 on "salmonella", 6 on "other mixed bacteria", and 34 experiments on "microbiota". The second group, "gastrointestinal protozoa", included 39 publications and 78 experiments, wherein 72 experiments referred to "coccidia" and 6 to "other protozoa".

The 148 experiments were in vivo trials with 83 plant species of 42 plant families ( $\triangleright$ Table 3 ). Most experiments were found for A. annua (13), followed by Origanum vulgare L. (9). Artemisia sieberi Besser was analyzed in 5 experiments, as well as Rosmarinus officinalis L. and Thymus vulgaris L. Echinacea purpurea (L.) Moench, 


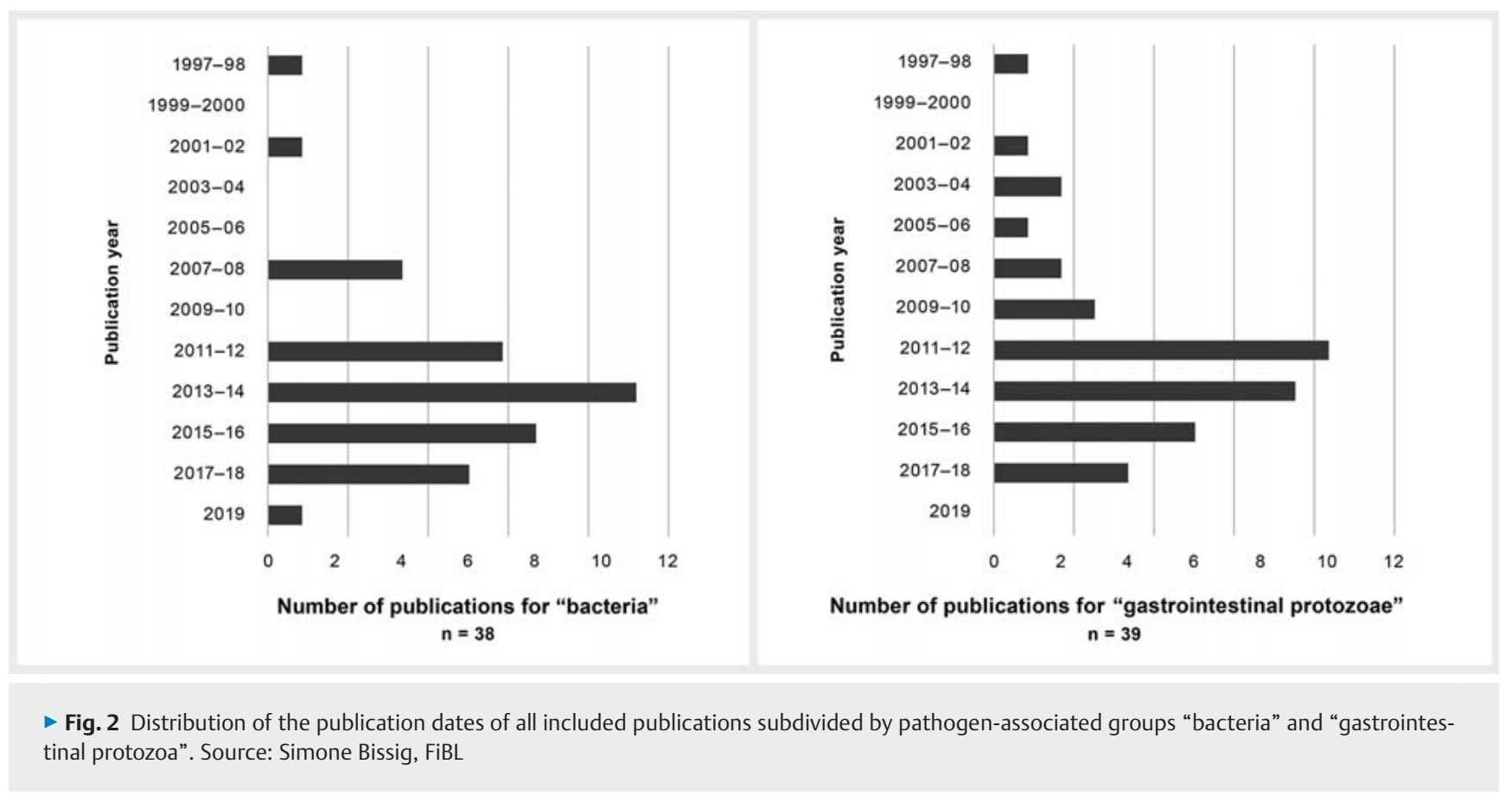

Peganum harmala L., and Allium sativum L. were represented in 4 experiments each. Most experiments (34) included the family Asteraceae, containing 11 plant species, followed by Lamiaceae with 28 experiments and 8 plant species. Apiaceae was included with 10 experiments, containing 9 plant species. Two or more experiments were found for 24 plant species ( $\triangleright$ Table 4). Fifty-nine plant species were only represented with 1 in vivo experiment.

The most commonly investigated poultry type in the experiments included in this review was broilers with 102 out of 148 experiments, followed by 39 with laying hens, 5 included turkeys, and 2 used quails. In 106 out of 148 experiments, the birds were randomly allocated to the trial groups; in 4 experiments, the allocation was described as equally distributed according to body weight. In the remaining 38 experiments, information about the method of distribution was missing. At the start of the trial, the age of the animals ranged from 1 day (90 experiments) to 280 days ( 1 trial with 40 -wk old layers). The treatment duration ranged from 1 day up to 49 days.

The most frequently used pharmaceutical preparation consisted of extracts (103 experiments: 20 with alcoholic, 7 with aqueous, and 54 with not further specified extracts, and 22 with essential oils), followed by the crude plant material (40 experiments) and other pharmaceutical preparations (5 experiments). In 102 experiments, administration of plant preparations was via feed, followed by 30 experiments using drinking water for administration. Administration by forced feeding directly into the animals' crop was performed in 16 experiments. In a total of 51 2-armed experiments, 45 had a "negative control group", 2 a "positive control group", and 4 a vaccinated group as control. In 99 experiments, a 3-armed design was chosen, in most cases comprising a "negative and positive control group" with the medicinal plant preparation.
The outcome of the trials resulted in the following scores: 274 “+”, 241 "0", and 37 “-" ( $\triangleright$ Table 4). Most of the experiments investigated performance effects (125 on growth or egg production, 69 focused on feed intake and 77 analyzed feed conversion rate), while "antiadhesive", "anti-inflammatory", and "antioxidant" effects were evaluated less frequently $(6,6,15)$. Antibacterial activity was tested in 71 experiments, whereof 46 showed a positive effect according to the defined criteria in this review, 24 studies showed no effect compared to the control group, and 1 study had a negative outcome. Prebiotic effects were studied in 46 experiments, resulting in 19 positive and 27 zero effects. Antiprotozoal activity of plants or plant extracts in poultry was investigated in 77 experiments, whereof 49 showed positive effects, 26 found no difference compared to the control group, and in 2 experiments, the plant had a negative effect compared to the control group.

Based on the data of this review with a total of 83 investigated plant species, 19 plant species showed an antibacterial effect, 35 plant species showed an antiprotozoal effect, and 3 plant species had a prebiotic effect $(\triangleright$ Table 4 , Table 15 , Supporting Information). Ten plant species out of the 5 families Amaryllidaceae, Asteraceae, Lamiaceae, Nitrariaceae, and Xanthorrhoeaceae showed both in vivo antibacterial and in vivo antiprotozoal activities in chicken and turkeys: A. sativum, Aloe secundiflora Engl., Aloe vera L., A. annua, A. sieberi, E. purpurea, O. vulgare, Salvia officinalis L., T. vulgaris, and P. harmala. Fifteen plant species showed antibacterial as well as prebiotic effects, often detected within the same study.

Regarding the total score for all experiments, the positive outcome for antibacterial (65\%), antiprotozoal (63\%), antiadhesive (67\%), antioxidant (87\%), anti-inflammatory (100\%), and immunotropic (71\%) effects overweighed compared to "zero" and "negative" effects ( $\triangleright$ Table 4 ). The outcome for the production 
- Table 3 Medicinal plants used in in vivo trials with bacterial or gastrointestinal protozoal infections in poultry published between 1997 and 2019 in peer-reviewed journals: incidence of plant families and species.

\begin{tabular}{|c|c|c|c|}
\hline Family & $\begin{array}{l}\text { Number of experi- } \\
\text { ments per family }\end{array}$ & $\begin{array}{l}\text { Number of species } \\
\text { per family }\end{array}$ & $\begin{array}{l}\text { Species in alphabetic order (in brackets: experiments per species, } \\
\text { if more than 1) }\end{array}$ \\
\hline Asteraceae & 34 & 11 & $\begin{array}{l}\text { Achillea millefolium L. (3), Ageratum conyzoides (L.) L, Artemisia annua L. (13), } \\
\text { Artemisia asiatica (Pamp.) Nakai ex Kitam., Artemisia sieberi Besser (5), Artemisia } \\
\text { vestita Wall. ex Besser, Artemisia vulgaris L., Bidens pilosa L. (3), Echinacea purpurea } \\
\text { (L.) Moench (4), Eclipta alba (L.) Hassk., Inula helenium L. }\end{array}$ \\
\hline Lamiaceae & 28 & 8 & $\begin{array}{l}\text { Mentha x piperita L. (2), Mentha spicata L., Origanum majorana L. (2), Origanum } \\
\text { minutiflorum O.Schwarz \& P. H.Davis, Origanum vulgare L. (9), Rosmarinus officinalis } \\
\text { L. (5), Salvia officinalis L. (2), Teucrium polium L., Thymus vulgaris L. (5) }\end{array}$ \\
\hline Apiaceae & 10 & 9 & $\begin{array}{l}\text { Bupleurum chinense DC., Centella asiatica (L.) Urb, Coriandrum sativum L. (2), } \\
\text { Cuminum cyminum L., Ferulago angulata (Schltdl.) Boiss. Foeniculum vulgare Mill., } \\
\text { Heracleum persicum Desf. ex Fisch., C. A.Mey. \& Avé-Lall., Torilis japonica (Houtt.) } \\
\text { DC., Trachyspermum ammi (L.) Sprague) }\end{array}$ \\
\hline Leguminosae & 7 & 7 & $\begin{array}{l}\text { Acacia decurrens Willd., Astragalus membranaceus (Fisch.) Bunge, Gleditsia japonica } \\
\text { Miq., Lupinus angustifolius L., Sophora flavescens Aiton, Styphnolobium japonicum } \\
\text { (L.) Schott, Trigonella foenum-graecum L. }\end{array}$ \\
\hline Xanthorrhoeaceae & 5 & 2 & Aloe secundiflora Engl. (2), Aloe vera (L.) Burm.f. (3) \\
\hline Amaryllidaceae & 4 & 1 & Allium sativum L. (4) \\
\hline Nitrariaceae & 4 & 1 & Peganum harmala L. (4) \\
\hline Euphorbiaceae & 3 & 2 & Euphorbia hirta L. (2), Manihot esculenta Crantz \\
\hline Poaceae & 3 & 1 & Saccharum officinarum L. (3) \\
\hline Ranunculaceae & 3 & 2 & Nigella sativa L. (2), Pulsatilla cernua (Thunb.) Bercht. ex J. Presl \\
\hline Rutaceae & 3 & 3 & Citrus x bergamia Risso \& Poit., Citrus limon (L.) Osbeck, Citrus sinensis (L.) Osbeck \\
\hline Simaroubaceae & 3 & 1 & Brucea javanica (L.) Merr. (3) \\
\hline Vitaceae & 3 & 1 & Vitis vinifera L. (3) \\
\hline Anacardiaceae & 2 & 2 & Anacardium occidentale L., Rhus coriaria L. \\
\hline Aquifoliaceae & 2 & 1 & Ilex paraguariensis A. St.-Hil. (2) \\
\hline Arecaceae & 2 & 2 & Areca catechu L., Serenoa repens (W.Bartram) Small \\
\hline Lauraceae & 2 & 1 & Cinnamomum verum J.Presl (2) \\
\hline Myrtaceae & 2 & 1 & Syzygium aromaticum (L.) Merr. \& L. M.Perry (2) \\
\hline Oleaceae & 2 & 2 & Forsythia suspensa (Thunb.) Vahl, Fraxinus ornus L. \\
\hline Scrophulariaceae & 2 & 2 & Eremophila glabra (R.Br.) Ostenf., Scrophularia striata Boiss. \\
\hline Theaceae & 2 & 1 & Camellia sinensis (L.) Kuntze (2) \\
\hline Altingiaceae & 1 & 1 & Liquidambar orientalis Mill. \\
\hline Burseraceae & 1 & 1 & Commiphora swynnertonii Burtt \\
\hline Combretaceae & 1 & 1 & Combretum indicum (L.) Defilipps \\
\hline Cucurbitaceae & 1 & 1 & Cucurbita pepo L. \\
\hline Ganodermataceae & 1 & 1 & Ganoderma lucidum (Curtis) P. Karst. \\
\hline Hydrangeaceae & 1 & 1 & Dichroa febrifuga Lour. \\
\hline Lythraceae & 1 & 1 & Punica granatum L. \\
\hline Malvaceae & 1 & 1 & Abelmoschus esculentus (L.) Moench \\
\hline Marasmiaceae & 1 & 1 & Lentinula edodes (Berk.) Pegler \\
\hline Meliaceae & 1 & 1 & Melia azedarach L. \\
\hline Menispermaceae & 1 & 1 & Sinomenium acutum (Thunb.) Rehder \& E.H.Wilson \\
\hline
\end{tabular}


Table 3 Continued

\begin{tabular}{|l|l|l|l|}
\hline Family & $\begin{array}{l}\text { Number of experi- } \\
\text { ments per family }\end{array}$ & $\begin{array}{l}\text { Number of species } \\
\text { per family }\end{array}$ & $\begin{array}{l}\text { Species in alphabetic order (in brackets: experiments per species, } \\
\text { if more than } 1 \text { ) }\end{array}$ \\
\hline Moringaceae & 1 & 1 & Moringa olifera L. \\
\hline Musaceae & 1 & 1 & Musa paradisiaca L. \\
\hline Piperaceae & 1 & 1 & Piper sarmentosum Roxb. \\
\hline Polygonaceae & 1 & 1 & Polygonum aviculare L. \\
\hline Quillajaceae & 1 & 1 & Quillaja saponaria Molina \\
\hline Rubiaceae & 1 & 1 & Morinda citrifolia L. \\
\hline Schisandraceae & 1 & 1 & Illicium verum Hook.f. \\
\hline Taxaceae & 1 & 1 & Torreya nucifera (L.) Siebold \& Zucc. \\
\hline Tremellaceae & 1 & 1 & Tremella fuciformis (Berk.) \\
\hline Ulmaceae & 1 & 1 & Ulmus macrocarpa Hance \\
\hline Urticaceae & 1 & 1 & Urtica dioica L. \\
\hline
\end{tabular}

parameters, including improved growth, feed intake, and feed conversion rate was mostly "zero" (46\%, 58\%, 57\%). Prebiotic effects were found, and positive (41\%) and zero (57\%) outcomes were almost equally represented. In summary, 274 positive effects (50\%) predominated over 241 zero effects (44\%) and 37 negative effects (7\%).

\section{Discussion}

Detection of an increasing number of antimicrobial-resistant pathogens (against antibiotic as well as anticoccidial drugs) in poultry has resulted in an intensified search for alternative treatment methods. Medicinal plants and their extracts might represent an option for alternative treatments to reduce or replace the common therapy with antimicrobials.

An increase in the number of publications per year was observed around 2010. This outcome could be associated with the EU's ban on antibiotics as growth promoters in livestock feed in 2006, leading to an increasing interest in exploring alternative ways to prevent infectious diseases. Since 2016, the number of publications decreased again, which is difficult to explain, as the problem of antimicrobial input in the worldwide poultry industry has not been resolved yet.

\section{Evaluation of the methodology}

This systematic review was designed according to the PRISMA statement and AMSTAR measurement tool [28-30]. The risk of introducing database bias was reduced by using 2 different and independent databases and by using the Mesh Term functions on PubMed. The deliberately less specific search strategy led to over 3000 hits in the first search, and only around 3\% of the references were finally included in the review. However, this is consistent with studies using comparable methodology [24]. To reach a high level of validity, only trials with control groups were included. However, 2 methodological limitations might have led to a certain bias: Besides 106 experiments where a randomized distribution of the birds to the trial groups was clearly stated, no information about the distribution was available in 38 of the 148 included experiments. Furthermore, blinding is unusual in herbal feeding trials with poultry because in trials with oral administration of plant raw material, essential oils, or simple plant extracts, blinding is hardly possible due to the sensory properties of the used plant material. The scoring system allowed comparisons of a large number of experiments and helped to identify the most relevant plant species. Nevertheless, the total score must be interpreted with caution. Plant species with a large number of experiments and a large number of parameters measured per experiment had a priori the highest chance to reach the highest total scores, which might have caused a bias. The median number of parameters measured per experiment was 3 with a range of 1 to 7 . Even publications measuring a high number of parameters did not clearly state if a Bonferroni correction was conducted. However, detailed proof of the statistical methods was not conducted, and these studies with a potential flaw in statistical methods were still included because this review was not designed as a meta-analysis but rather as a qualitative systematic review.

The outcomes of different studies regarding the same plant species were often not uniform. One explanation might be the variability of natural products within the same plant species. Environmental factors like climate and geographic conditions, time of the year, soil, method of cultivation, and storage affect the phytochemical composition [34-36]. Therefore, the amounts of active constituents can differ in each product sample as reported, for example, for S. officinalis [37] or A. annua [36]. Furthermore, it is important to consider that the amounts of active constituents can depend on the type of extract and the extraction method used [38], as well as the parts of the plant used, as described for Forsythia suspensa (Thunb.) Vahl or Aloe spp. [39,40]. Unfortunately, detailed information about the natural products compounds of the used plants was broadly missing. Last, the mode and duration of the administration for prophylactic or therapeutic use have an impact on the effectiveness of medicinal plants [41,42]. 


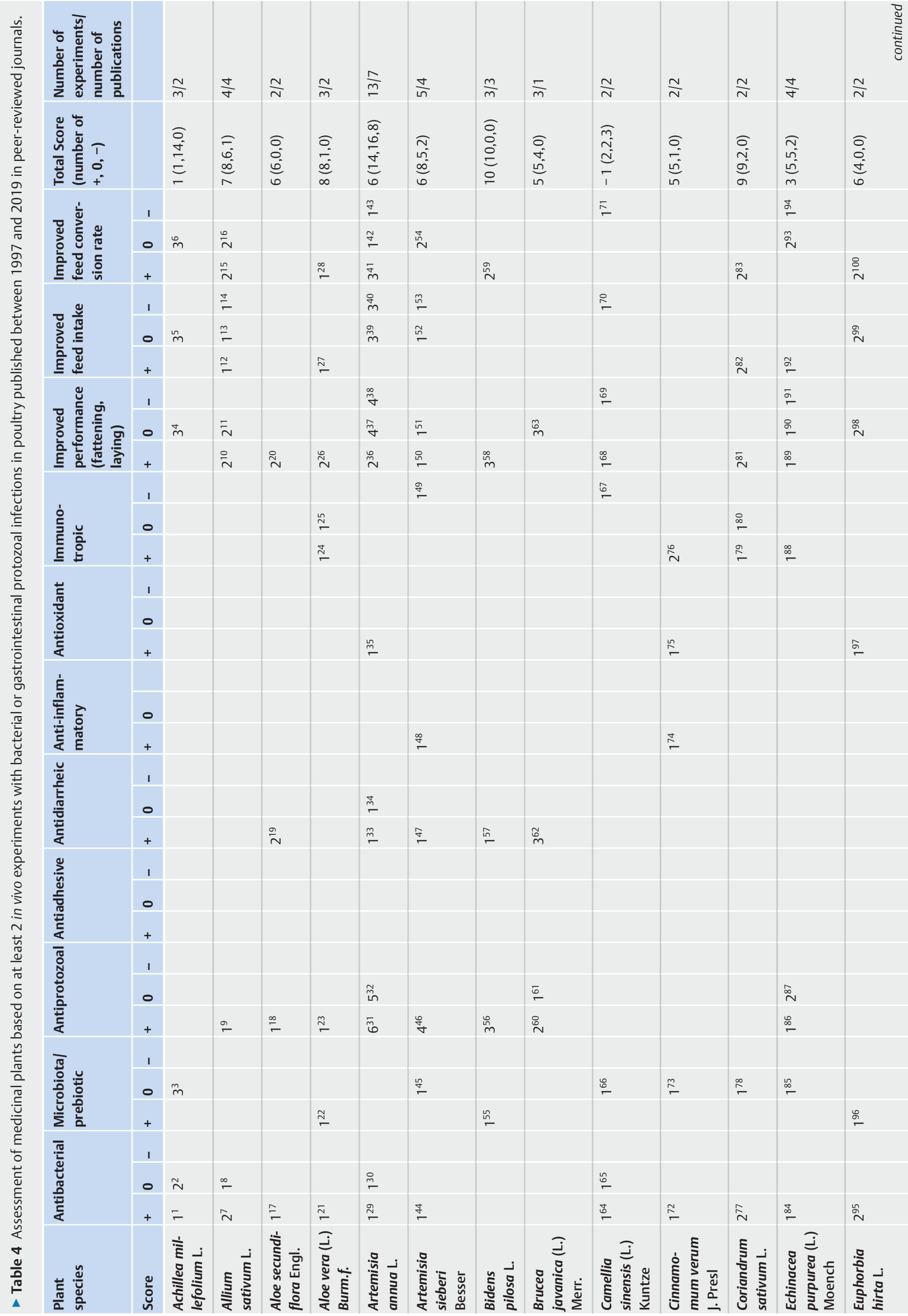




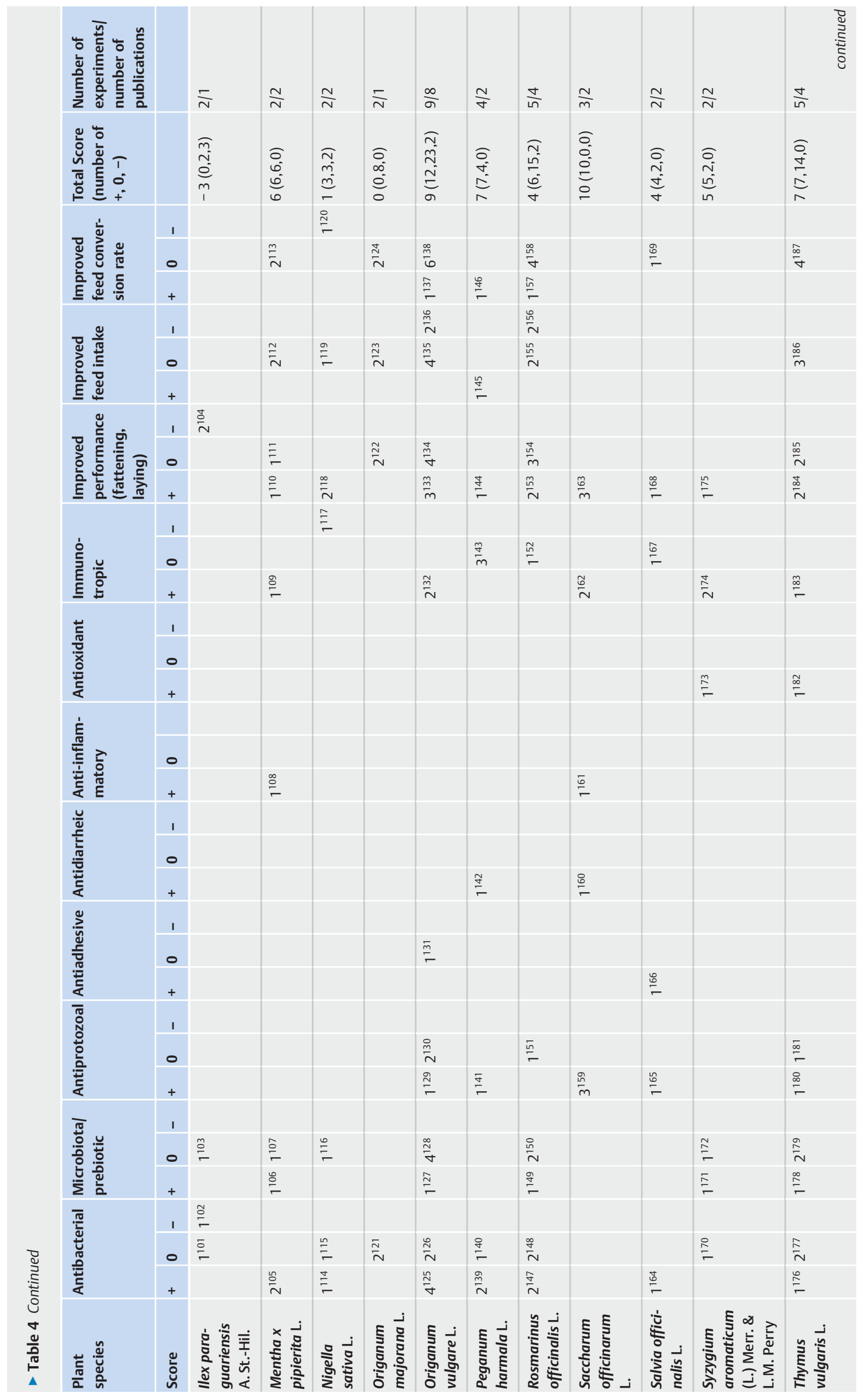




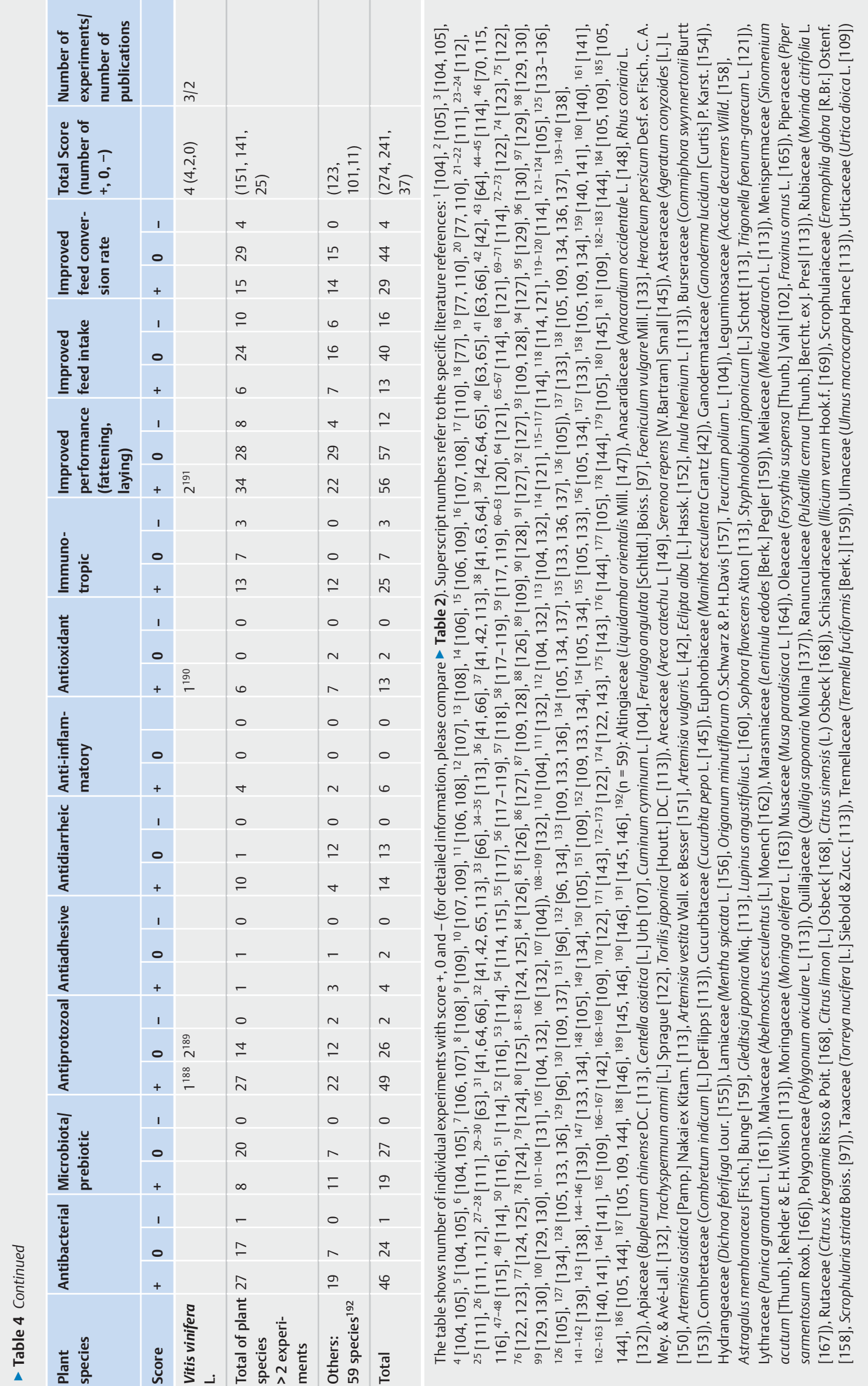




\section{Antibacterial, anticoccidial, and prebiotic active plant species}

Several plant species including A. sativum, A. secundiflora, A. vera, A. annua, A. sieberi, E. purpurea, O. vulgare, S. officinalis, T. vulgaris, and $P$. harmala showed antibacterial, antiprotozoal, and, in some plant species, also prebiotic activities. In accordance, antimicrobial activities were also shown in these plants in numerous in vitro studies [43-56]. Interestingly, no study analyzed the antibacterial and antiprotozoal effect at the same time, even if in practice, pathologies might often be caused by such combined infections.

It is still not obvious why some medical plants act antibacterially concerning pathogens and prebiotic (e.g., by elevation of the lactobacillus population) at the same time. It has been shown or hypothesized that gram-negative and zoopathic bacteria utilize acylated homoserine lactone (AHL) for their communication system [57]. This system has been named quorum sensing (QS), and it has been demonstrated to regulate various activities such as virulence factors, sporulation, and biofilm formation $[57,58]$. One way of inhibiting AHL biosynthesis includes effects on Luxltype synthase and/or LuxR-type receptor proteins as shown for $O$. vulgare and $T$. vulgaris and other Lamiaceae species as well as their direct antibiofilm activity [57], also known for other plant species [59]. Bifidobacteria and Lactobacilli may produce metabolic end-products that lower the gut $\mathrm{pH}[60,61]$ and inhibit the growth of pathogens such as E. coli, Salmonella thyphimurium, and C. perfringens [61]. Animals fed with antibiotics had a thinned mucosal layer and a decreased gut-weight as well as a decrease in protective microflora: thus, antibiotics were shown to weaken the ecosystem in the gut and facilitate pathogen survival [61, $62]$. Powering up the healthy gut microflora with plants with possible prebiotic activities might enhance the nonpathogen bacteria population. The sum of these effects might lead to antibacterial and prebiotic effects at the same time. However, the clinical evidence of such effects is still controversially discussed.

\section{Some outstanding single plant species}

Based on the aim to identify the most promising plant species for future research, species that were represented by a high number of experiments and species that showed a high total score will be discussed in detail in alphabetical order: A. annua, A. sieberi, A. vera, A. secundiflora, Bidens pilosa, Coriandrum sativum L., Mentha $x$ piperita L., and $O$. vulgare.

A. annua was represented in 13 experiments and resulted in a total score of 6 (14 positive, 16 zero, 8 negative effects). In 11 experiments the antiprotozoal effect was evaluated, wherein 6 were positive and 5 showed no effect. Detrimental effects were found especially in performance, related to reduced body weight [41, $63,64]$ or reduced feed intake [63-65]. These results might be attributed to the lowered palatability of the feed, due to the bitter and strong taste of $A$. annua, imposed by contained sesquiterpenes, mainly artemisinin [63-65]. In contrast, there is some evidence that $A$. annua improves the feed conversion rate $[63,66]$. The anticoccidial effect showed a linear relationship between artemisinin dose used and oocyst output $[41,63]$. Overall, antiparasitic effects of artemisinin and its derivates were confirmed in many in vitro and in vivo studies [67]. Nevertheless, A. annua contains a broad spectrum of secondary metabolites [68], which vary depending, for example, on geographic origin [36]. This might be one reason for divergent results in some effects. While it is well documented that artemisinin affects different metabolic pathways of malaria parasites [69], the mode of action in gastrointestinal poultry coccidia is still unknown.

A. sieberi was represented with 5 experiments resulting in a total score of 6 ( 8 positive, 5 zero, and 2 negative effects). Four experiments confirmed antiprotozoal effects. In addition, $A$. sieberi was demonstrated to reveal anti-inflammatory effects. The chemical component responsible for the antiprotozoal and the anti-inflammatory effect might be again artemisinin, similar to the effect of A. annua [70]. Artemisinin has been shown to exert immunomodulatory effects through its inhibition of several immune cells and related signaling pathways [71]. A. sieberi has been demonstrated to contain sesquiterpene lactones, leading to antimicrobial activity in vitro against both gram-negative and grampositive like E. coli, Pseudomonas aeruginosa, and Staphylococcus aureus [47]. As already reported for Genus Artemisia, European farmers used Artemisia absinthum traditionally in laying hens for its antidiarrheal, intestinal anti-inflammatory, and anti-infective as well as antiparasitic effects. [21].

A. vera showed a total score of 8 ( 8 positive, 1 zero effect) represented in 3 experiments. Besides antibacterial and antiprotozoal effects, improved performance, feed intake, and feed conversion rate, $A$. vera also led to immunotropic and prebiotic effects. Its antimicrobial potential might be attributed, for example, to flavonoids $[68,72]$, or anthraquinones are likely to inhibit protein synthesis in bacteria [73]. Contained polysaccharides enhance phagocytosis-activity and may therefore be responsible for the in vivo antibacterial effect shown in one of the experiments [74]. Contained catechol, a hydroxylated phenol, was reported to exert antimicrobial activities [74]. The immunotropic effect might be given through the polysaccharide acemannan, which has been reported to exert immunostimulating effects in vitro [75] and in particular to activate macrophages in vivo in chicken [76]. Wholeplant extracts but also several single components of $A$. vera showed anti-inflammatory activities via different modes of action such as inhibition of proinflammatory cytokines or cyclooxygenase pathway [73].

A. secundiflora, represented in 2 experiments, showed consistent positive effects (antibacterial, antiprotozoal, antidiarrheic effects, and improved performance) with a total score of 6 . The presence of terpenoids, flavonoids, and tannins is responsible for these effects [77].

The Asteraceae $B$. pilosa reached a total score of 10 ( 10 positive effects) out of 3 experiments. All experiments showed antiprotozoal effects, improved performance, and antidiarrheic and prebiotic effects. $B$. pilosa is an extraordinary source of natural products, containing predominantly polyacetylenes and flavonoids, and these have been demonstrated to be anti-inflammatory [78], antioxidant [79], and antibacterial [79, 80]. Phenols, like luteolin, ethyl caffeate, and polyynes were reported to be the major antiinflammatory natural products present in B. pilosa [81]. B. pilosa's potential to exert anticoccidial properties might be caused by cytopiloyne inhibiting the oocyst sporulation and invading into the cell, as demonstrated in in vitro and in vivo experiments [82]. 
C. sativum, represented with 2 experiments, resulted in a total score of 9 points ( 9 positive, 2 zero effects). Antibacterial and immunotropic effects, as well as improved performance, have been reported. The essential oil of $C$. sativum has been described to have antibacterial action in vitro [83], with its effect on gram-positive and gram-negative pathogens being sometimes more potent than the antibiotic rifaximin [84]. This effect is most probably due to an increase in bacterial membrane permeability and the loss of respiratory activity due to complex interactions between the membrane and several components of the essential oil [85]. Per the outcome of this systematic review, a study on feeding rainbow trouts with $C$. sativum seed extract optimized growth performance [86], possibly through stimulating the secretion of digestive enzymes [87].

Two experiments on $M$. x piperita were found, resulting in a total score of 6 points ( 6 positive, 6 zero effects). Both experiments confirmed an in vivo antibacterial effect. Furthermore, an anti-inflammatory and immunotropic effect could be shown. Interestingly, a plant species from the same genus, Mentha suaveolens Ehrh. has been traditionally used by farmers in Spain for antiprotozoal therapeutic action in laying hens [21]. The main components of the essential oil from leaves of $M$. piperita are menthol, menthone, and menthyl acetate, and they were shown to effectively inhibit the growth of 18 multidrug-resistant S. aureus strains in an in vitro trial [88]. Similar results were found in another in vitro trial on pathogenic methicillin-resistant $S$, aureus [89]. Essential oil of $M$. piperita resulted in an antioxidant activity that was analyzed by measuring the reduction of the radical cation [90] and might explain the anti-inflammatory effects also found in the present study. It has been reported that menthol suppresses the expression of prostaglandin E2, leukotriene B4, and interleukin (IL)- $\beta 2$ and therefore exerts anti-inflammatory effects [91].

0 . vulgare was found in 9 experiments, resulting in a total score of 10 (12 positive, 23 zero, 2 negative). Improved performance and antibacterial and anticoccidial properties were measured, and 5 experiments confirmed a prebiotic action. 0 . vulgare has been traditionally used in Switzerland in hens with gastrointestinal disorders [17]. Five experiments used the oregano essential oil, which is rich in phenolic compounds, containing carvacrol as its main compound $[90,92]$. Carvacrol has been reported to have antibacterial effects in vitro (i.e., due to the phenols containing an isopropyl group at the para-position $[93,94]$ and via altering the structure of phospholipid membranes of bacteria) [95]. In vitro, carvacrol's immunomodulating properties led to a significant decrease in phagocytosis [92], but IL-6 production was not significantly affected. This is in contrast to our assessment, where 1 experiment showed enhanced lgM+ cells [96].

Some plant species were only represented in 1 experiment. Four plant species stood out due to a high total score: Scrophularia striata Boiss and Ferulago angulata (Schltdl.) Boiss (each 6 scoring points) and F. suspensa and Mentha spicata L. (each 5 scoring points). None of these plant species resulted in any negative effects. Therefore, they are shortly discussed in the following, although a plant species represented with only 1 experiment is less meaningful.

S. striata was shown to be antibacterial in vivo against coliform bacteria, prebiotic on Lactobacillus, immunotropic, and causing improved performance in broilers [97]. It is traditionally used for infectious diseases, allergies, and chronic inflammatory diseases [98] and to treat constipation in laying hens [21]. Its action has been reported to be antimicrobial, anti-inflammatory, and antioxidative and is caused by contained gallic acid, flavonoids, and phenylpropanoids $[98,99]$.

F. angulata showed antibacterial, prebiotic, and immunotropic effects and improved fattening, feed intake, and feed conversion rate in broilers [97]. Constituents such as $\alpha$-terpineol, terpenen-4ol, $\alpha$-pinene, $\beta$-pinene, and $\rho$-cymene have been reported to be anti-inflammatory [100]. $\alpha$-Pinene is high concentrated in F. angulata and known for its antimicrobial properties [35], most probably via decreasing the bacterial membrane integrity [101].

F. suspensa resulted in antibacterial, antioxidant, immunotropic, and prebiotic effects, improved growth, and improved feed intake in broilers in vivo [102]. An in vitro trial showed that forsythiaside (a phenylethanoid glycoside) and forsythin (a lignan), 2 recently identified natural compounds $(n=237)$ of $F$. suspensa [103], inhibited the growth of E. coli, P. aeruginosa, and S. aureus. The same study also gave evidence for the antioxidant activity of $F$. suspensa. The improved weight gain might be explained by the repression of the growth of $E$. coli and the improved growth of lactobacillus [39].

\section{Conclusions}

Data from this systematic review indicate that medicinal plants have the potential to reduce the use of antibiotics and antiprotozoals in poultry production. O. vulgare, C. sativum, A. annua, and $B$. pilosa are promising plant species for prophylaxis and therapy of bacterial and protozoal diseases in poultry. Several further plant species are interesting candidates for future research. Different dosages and phytochemical compositions of the used material may impact the outcome of the systematic review.

A comprehensive and transparent description of the used herbal preparations, as already recommended from the CONSORT group for human clinical trials with herbal interventions nearly 15 years ago, should be considered in future trials with poultry. The missing patentability for phytogenic feed additives might be addressed by phytochemical fingerprints in combination with some overall descriptions and analyses of the used plant material.

\section{Supporting information}

S1: Protocoll of the systematic review. Table 1S: Detailed information on the 148 experiments used for the final analysis of the systematic review.

\section{Contributors' Statement}

Conception and design of the work: H. Ayrle, M. Walkenhorst, V. Maurer, M. Mevissen, M. Melzig, T.S. Dalgaard; data collection: P. Farinacci, H. Ayrle; analysis and interpretation of the data: P. Farinacci, H. Ayrle, V. Maurer, M. Walkenhorst, M. Mevissen, M. Melzig, T.S. Dalgaard; statistical analysis: P. Farinacci, M. Walkenhorst, M. Mevissen; drafting the manuscript: P. Farinacci; critical revision of the manuscript: P. Farinacci, H. Ayrle, V. Maurer, M. Walkenhorst, M. Mevissen, M. Melzig, T.S. Dalgaard. 


\section{Acknowledgements}

We thank Simone Bissig (FiBL) for designing the figures and Martin Breu (FiBL) for technical support. We thank the Swiss retailer Migros for funding this work.

\section{Conflict of Interest}

The authors declare that they have no conflicts of interest. The funding institution was not involved in the study design, collection, analysis, and interpretation of the obtained data or in the writing of the manuscript.

\section{References}

[1] Alexandratos N, Bruinsma J. World Agriculture Towards 2030/2050: The 2012 Revision. Rome: Food and Agriculture Organization of the United Nations; 2012

[2] Lutful Kabir SM. Avian colibacillosis and salmonellosis: a closer look at epidemiology, pathogenesis, diagnosis, control and public health concerns. Int J Environ Res Public Health 2010; 7: 89-114

[3] Blake DP, Tomley FM. Securing poultry production from the ever-present Eimeria challenge. Trends Parasitol 2014; 30: 12-19

[4] Noack S, Chapman HD, Selzer PM. Anticoccidial drugs of the livestock industry. Parasitol Res 2019; 118: 2009-2026

[5] European Medicines Agency. Sales of veterinary antimicrobial agents in 31 European countries in 2017. 2019. Accessed July 20, 2021 at: www. ema.europa.eu/en/documents/report/sales-veterinary-antimicrobialagents-31-european-countries-2017_en.pdf

[6] Boovaragamoorthy GM, Anbazhagan M, Piruthiviraj P, Pugazhendhi A, Kumar SS, Al-Dhabi NA, Mohammed Ghilan AK, Arasu MV, Kaliannan T. Clinically important microbial diversity and its antibiotic resistance pattern towards various drugs. J Infect Public Health 2019; 12: 783-788

[7] Lan LH, Sun BB, Zuo BX, Chen XQ, Du AF. Prevalence and drug resistance of avian Eimeria species in broiler chicken farms of Zhejiang province, China. Poult Sci 2017; 96: 2104-2109

[8] Schwarz A, Loeffler S, Kadlec K. Bacterial resistance to antimicrobial agents and its impact on veterinary and human medicine. Vet Dermatol 2017; 28: 82-e19

[9] Roth N, Käsbohrer A, Mayrhofer S, Zitz U, Hofacre C, Domig KJ. The application of antibiotics in broiler production and the resulting antibiotic resistance in Escherichia coli: A global overview. Poult Sci 2019; 98: 1791-1804

[10] Peek HW, Landman W]. Coccidiosis in poultry: anticoccidial products, vaccines and other prevention strategies. Vet Q 2011; 31: 143-161

[11] European Union. Regulation (EC) No 1831/2003 of the European Parliament and of the council of 22 September 2003 on additives for use in animal nutrition. OJEU 2003. Accessed July 20, 2021 at: https://eur-lex. europa.eu/legal-content/EN/TXT/PDF/?uri=CELEX:32003R1831 \&from $=e n$

[12] Institute of Veterinary Pharmacology and Toxicology Zurich. CliniPharm CliniTox. 2019. Accessed November 7, 2019 at: https://www.vetpharm. uzh.ch/cpthome.htm

[13] Williams RB. Intercurrent coccidiosis and necrotic enteritis of chickens: rational, integrated disease management by maintenance of gut integrity. Avian Pathol 2005; 34: 159-180

[14] Saif YM. Diseases of Poultry. Vol. 11. Ames, lowa: lowa State University Press; 2003

[15] Ojimelukwe AE, Emedhem DE, Agu GO, Nduka FO, Abah AE. Populations of Eimeria tenella express resistance to commonly used anticoccidial drugs in southern Nigeria. Int J Vet Sci Med 2018; 6: 192-200

[16] Disler M, Ivemeyer S, Hamburger M, Vogl CR, Tesic A, Klarer F, Meier B, Walkenhorst M. Ethnoveterinary herbal remedies used by farmers in four north-eastern Swiss cantons (St. Gallen, Thurgau, Appenzell Innerrhoden and Appenzell Ausserrhoden). J Ethnobiol Ethnomed 2014; 10: 32

[17] Mayer M, Zbinden M, Vogl CR, Ivemeyer S, Meier B, Amorena M, Maeschli A, Hamburger M, Walkenhorst M. Swiss ethnoveterinary knowledge on medicinal plants-a within-country comparison of Italian speaking regions with north-western German speaking regions. J Ethnobiol Ethnomed 2017; 13: 1

[18] Schmid K, Ivemeyer S, Vogl C, Klarer F, Meier B, Hamburger M, Walkenhorst M. Traditional use of herbal remedies in livestock by farmers in 3 Swiss cantons (Aargau, Zurich, Schaffhausen). Forsch Komplementmed 2012; 19: 125-136

[19] Mertenat D, Cero MD, Vogl CR, Ivemeyer S, Meier B, Maeschli A, Hamburger M, Walkenhorst M. Ethnoveterinary knowledge of farmers in bilingual regions of Switzerland-Is there potential to extend veterinary options to reduce antimicrobial use? J Ethnopharmacol 2020; 246: 112184

[20] Bischoff T, Vogl CR, Ivemeyer S, Klarer F, Meier B, Hamburger H, Walkenhorst $\mathrm{M}$. Plant and natural product based homemade remedies manufactured and used by farmers of six central Swiss cantons to treat livestock. Livest Sci 2016; 189: 110-125

[21] Mayer M, Vogl CR, Amorena M, Hamburger M, Walkenhorst M. Treatment of organic livestock with medicinal plants: a systematic review of European ethnoveterinary research. Forsch Komplementarmed 2014; 21: 12

[22] Brendieck-Worm C, Melzig MF. Phytotherapie in der Tiermedizin. Leipzig, New York: Thieme; 2018

[23] Reichling J, Frater-Schröder M, Saller R, Fitzi-Rathgen J, Gachnian-Mirtscheva R. Heilpflanzenkunde für die Veterinärpraxis. 3 ed. Berlin: Springer; 2016

[24] Ayrle H, Mevissen M, Kaske M, Nathues H, Gruetzner N, Melzig M, Walkenhorst M. Medicinal plants-prophylactic and therapeutic options for gastrointestinal and respiratory diseases in calves and piglets? A systematic review. BMC Vet Res 2016; 12: 89

[25] Hashemi SR, Davoodi H. Phytogenics as new class of feed additive in poultry industry. J Anim Vet Adv 2010; 9: 2295-2304

[26] Gadde U, Kim WH, Oh ST, Lillehoj HS. Alternatives to antibiotics for maximizing growth performance and feed efficiency in poultry: a review. Anim Health Res Rev 2017; 18: 26-45

[27] Wallace R], Oleszek W, Franz C, Hahn I, Baser KH, Mathe A, Teichmann K. Dietary plant bioactives for poultry health and productivity. Br Poult Sci 2010: 51: 461-487

[28] Liberati A, Altman DG, Tetzlaff J, Mulrow C, Gøtzsche PC, loannidis JP, Clarke M, Devereaux PJ, Kleijnen J, Moher D. The PRISMA statement for reporting systematic reviews and meta-analyses of studies that evaluate health care interventions: explanation and elaboration. Plos Medicine 2009; 6

[29] Moher D, Liberati A, Tetzlaff J, Altman DG; PRISMA Group. Preferred reporting items for systematic reviews and meta-analyses: the PRISMA statement. J Clin Epidemiol 2009; 62: 1006-1012

[30] Shea B], Grimshaw JM, Wells GA, Boers M, Andersson N, Hamel C, Porter AC, Tugwell P, Moher D, Bouter LM. Development of AMSTAR: a measurement tool to assess the methodological quality of systematic reviews. Bmc Med Res Methodol 2007; 7: 10

[31] Accessed February 1, 2018 at: www.webofscience.com/wos/woscc/ basic-search

[32] Accessed February 1, 2019 at: https://pubmed.ncbi.nlm.nih.gov/

[33] Accessed November 15, 2020 at: http://theplantlist.org/

[34] Figueiredo AC, Barroso JG, Pedro LG, Scheffer JJC. Factors affecting secondary metabolite production in plants: volatile components and essential oils. Flavour Fragr 」 2008; 23: 213-226

[35] Ghasemi Pirbalouti A, Izadi A, Malek Poor F, Hamedi B. Chemical composition, antioxidant and antibacterial activities of essential oils from Ferulago angulata. Pharm Biol 2016; 54: 2515-2520 
[36] Bilia AR, Santomauro F, Sacco C, Bergonzi MC, Donato R. Essential oil of Artemisia annua L.: an extraordinary component with numerous antimicrobial properties. Evid Based Complement Alternat Med 2014; 2014: 159819

[37] Ben Farhat M, Jordán M], Chaouech-Hamada R, Landoulsi A, Sotomayor JA. Variations in essential oil, phenolic compounds, and antioxidant activity of Tunisian cultivated Salvia officinalis L. J Agric Food Chem 2009; 57: 10349-10356

[38] Chudnicka A, Matysik G. Research of enzymatic activities of fresh juice and water infusions from dry herbs. J Ethnopharmacol 2005; 99: 281286

[39] Qu H, Zhang Y, Wang Y, Li B, Sun W. Antioxidant and antibacterial activity of two compounds (forsythiaside and forsythin) isolated from Forsythia suspensa. J Pharm Pharmacol 2008; 60: 261-266

[40] Salehi B, Albayrak S, Antolak H, Kręgiel D, Pawlikowska E, Sharifi-Rad M, Uprety Y, Tsouh Fokou PV, Yousef Z, Amiruddin Zakaria Z, Varoni EM, Sharopov F, Martins N, Iriti M, Sharifi-Rad J. Aloe genus plants: from farm to food applications and phytopharmacotherapy. Int J Mol Sci 2018; 19; 2843

[41] Allen PC, Lydon J, Danforth HD. Effects of components of Artemisia annua on coccidia infections in chickens. Poult Sci 1997; 76: 1156-1163

[42] Almeida GFD, Horsted H, Thamsborg SM, Hermansen JE. Strategies to Reduce Severity of Coccidia Infections in Organic Poultry Systems by the use of Plant Extracts. In: Rahmann G, Godinho D, eds. Tackling the Future Challenges of Organic Animal Husbandry. Proceedings of the 2nd OAHC. Hamburg/Trenthorst, Germany; 2012: 462-465

[43] Casella S, Leonardi M, Melai B, Fratini F, Pistelli L. The role of diallyl sulfides and dipropyl sulfides in the in vitro antimicrobial activity of the essential oil of garlic, Allium sativum L., and Leek, Allium porrum L. Phytother Res 2013; 27: 380-383

[44] Ankri S, Mirelman D. Antimicrobial properties of allicin from garlic. Microbes Infect 1999; 1: 125-129

[45] Mariita RM, Orodho JA, Okemo PO, Kirimuhuzya C, Otieno JN, Magadula J. Methanolic extracts of Aloe secundiflora Engl. inhibits in vitro growth of tuberculosis and diarrhea-causing bacteria. Pharmacognosy Res 2011; 3: 95-99

[46] Habeeb F, Shakir E, Bradbury F, Cameron P, Taravati MR, Drummond A], Gray Al, Ferro VA. Screening methods used to determine the anti-microbial properties of Aloe vera inner gel. Methods 2007; 42: 315-320

[47] Mohamed TA, Hegazy MF, Abd El Aty AA, Ghabbour HA, Alsaid MS, Shahat AA, Paré PW. Antimicrobial sesquiterpene lactones from Artemisia sieberi. J Asian Nat Prod Res 2017; 19: 1093-1101

[48] Gupta D, Kumar M. Evaluation of in vitro antimicrobial potential and GC-MS analysis of Camellia sinensis and Terminalia arjuna. Biotechnol Rep (Amst) 2017; 13: 19-25

[49] Brochot A, Guilbot A, Haddioui L, Roques C. Antibacterial, antifungal, and antiviral effects of three essential oil blends. Microbiologyopen 2017; 6

[50] Prabuseenivasan S, Jayakumar M, Ignacimuthu S. In vitro antibacterial activity of some plant essential oils. BMC Complement Altern Med 2006. 6: 39

[51] Sharifi-Rad M, Mnayer D, Morais-Braga MFB, Carneiro JNP, Bezerra CF, Coutinho HDM, Salehi B, Martorell M, Del Mar Contreras M, SoltaniNejad A, Uribe YAH, Yousaf Z, Iriti M, Sharifi-Rad J. Echinacea plants as antioxidant and antibacterial agents: from traditional medicine to biotechnological applications. Phytother Res 2018; 32: 1653-1663

[52] Tardugno R, Pellati F, Serio A, Paparella A, Benvenuti S. Phytochemical composition and in vitro antimicrobial activity of selected essential oils on foodborne pathogens. Abstracts of Papers of the American Chemical Society 2015; 249.

[53] Gericke S, Lübken T, Wolf D, Kaiser M, Hannig C, Speer K. Identification of new compounds from sage flowers (Salvia officinalis L.) as markers for quality control and the influence of the manufacturing technology on the chemical composition and antibacterial activity of sage flower extracts. J Agric Food Chem 2018; 66: 1843-1853

[54] Arshad N, Zitterl-Eglseer K, Hasnain S, Hess M. Effect of Peganum harmala or its beta-carboline alkaloids on certain antibiotic resistant strains of bacteria and protozoa from poultry. Phytother Res 2008; 22: 1533-1538

[55] Tabari MA, Youssefi MR, Moghadamnia AA. Antitrichomonal activity of Peganum harmala alkaloid extract against trichomoniasis in pigeon (Columba livia domestica). Br Poult Sci 2017; 58: 236-241

[56] Vasconcelos NG, Croda J, Simionatto S. Antibacterial mechanisms of cinnamon and its constituents: a review. Microb Pathog 2018; 120: 198203

[57] Deryabin D, Galadzhieva A, Kosyan D, Duskaev G. Plant-derived inhibitors of AHL-mediated quorum sensing in bacteria: modes of action. Int Mol Sci 2019; 20: 5588

[58] Nazzaro F, Fratianni F, Coppola R. Quorum sensing and phytochemicals. Int J Mol Sci 2013; 14: 12607-12619

[59] Naegeli H, Mevissen M, Walkenhorst M, Ayrle H, Kupper ]. Recent challenges in veterinary pharmacotherapy-could medicinal plants be an option? In: 65th International Congress and Annual Meeting of the Society for Medicinal Plant and Natural Product Research. PMIO 2017; 4 (Suppl. 1): S1-S202. doi:10.1055/s-0037-1608012

[60] Manning TS, Gibson GR. Microbial-gut interactions in health and disease. Prebiotics. Best Pract Res Clin Gastroenterol 2004; 18: 287-298

[61] Pan D, Yu Z. Intestinal microbiome of poultry and its interaction with host and diet. Gut Microbes 2014; 5: 108-119

[62] Choct M. Managing gut health through nutrition. Br Poult Sci 2009; 50: 9-15

[63] Engberg RM, Grevsen K, Ivarsen E, Fretté X, Christensen LP, Højberg O, Jensen BB, Canibe N. The effect of Artemisia annua on broiler performance, on intestinal microbiota and on the course of a Clostridium perfringens infection applying a necrotic enteritis disease model. Avian Pathol 2012; 41: 369-376

[64] de Almeida GF, Horsted K, Thamsborg SM, Kyvsgaard NC, Ferreira JF, Hermansen JE. Use of Artemisia annua as a natural coccidiostat in freerange broilers and its effects on infection dynamics and performance. Vet Parasitol 2012; 186: 178-187

[65] Thøfner IC, Liebhart D, Hess M, Schou TW, Hess C, Ivarsen E, Fretté XC, Christensen LP, Grevsen K, Engberg RM, Christensen JP. Antihistomonal effects of artemisinin and Artemisia annua extracts in vitro could not be confirmed by in vivo experiments in turkeys and chickens. Avian Pathol 2012; 41: 487-496

[66] Drăgan L, Györke A, Ferreira JF, Pop IA, Dunca I, Drăgan M, Mircean V, Dan I, Cozma V. Effects of Artemisia annua and Foeniculum vulgare on chickens highly infected with Eimeria tenella (Phylum Apicomplexa). Acta Vet Scand 2014; 56: 22

[67] Loo CS, Lam NS, Yu D, Su XZ, Lu F. Artemisinin and its derivatives in treating protozoan infections beyond malaria. Pharmacol Res 2017; 117: 192-217

[68] Wang SH, Hu YL, Liu TX. Plant distribution and pharmacological activity of flavonoids. Tradit Chin Med 2019; 4: 269-287

[69] Talman AM, Clain J, Duval R, Ménard R, Ariey F. Artemisinin bioactivity and resistance in Malaria parasites. Trend Parasitol 2019; 35: 953-963

[70] Arab HA, Rahbari S, Rassouli A, Moslemi MH, Khosravirad F. Determination of artemisinin in Artemisia sieberi and anticoccidial effects of the plant extract in broiler chickens. Trop Anim Health Prod 2006; 38: 497503

[71] Yao WB, Wang F, Wang $\mathrm{H}$. Immunomodulation of artemisinin and its derivatives. Science Bulletin 2016; 61: 1399-1406

[72] Tariq H, Zia M, Ihsan-Ul-Haq, Muhammad SA, Khan SA, Fatima N, Mannan A, Abbasi AM, Zhang M. Antioxidant, antimicrobial, cytotoxic, and protein kinase inhibition potential in Aloe vera L. Biomed Res Int 2019; 2019: 6478187 
[73] Kumar R, Singh AK, Gupta A, Bishayee A, Pandey AK. Therapeutic potential of Aloe vera-a miracle gift of nature. Phytomedicine 2019; 60: 152996

[74] Radha MH, Laxmipriya NP. Evaluation of biological properties and clinical effectiveness of Aloe vera: a systematic review. J Tradit Complement Med 2015; 5: 21-26

[75] Harlev E, Nevo E, Lansky EP, Ofir R, Bishayee A. Anticancer potential of aloes: antioxidant, antiproliferative, and immunostimulatory attributes. Planta Med 2012; 78: 843-852

[76] Djeraba A, Quere P. In vivo macrophage activation in chickens with Acemannan, a complex carbohydrate extracted from Aloe vera. Int J Immunopharmacol 2000; 22: 365-372

[77] Kaingu F, Liu D, Wang L, Tao J, Waihenya R, Kutima H. Anticoccidial effects of Aloe secundiflora leaf extract against Eimeria tenella in broiler chicken. Trop Anim Health Prod 2017; 49: 823-828

[78] Horiuchi M, Seyama Y. Antiinflammatory and antiallergic activity of Bidens pilosa L. var. radiata SCHERFF. J Health Sci 2006; 52: 711-717

[79] Farah D, Xuan TD, Yasuda M, Tawata S. Chemical composition and antioxidant, antibacterial and antifungal activities of the essential oils from Bidens pilosa Linn. var. Radiata. Food Control 2008; 19: 346-352

[80] Rabe T, van Staden J. Antibacterial activity of South African plants used for medicinal purposes. J Ethnopharmacol 1997; 56: 81-87

[81] Bartolome AP, Villasenor I, Yang WC. Bidens pilosa L. (Asteraceae): botanical properties, traditional uses, phytochemistry, and pharmacology. Evid Based Complement Alternat Med 2013; 2013: 340215

[82] Yang WC, Yang CY, Liang YC, Yang CW, Li WQ, Chung CY, Yang MT, Kuo TF, Lin CF, Liang CL, Chang CL. Anti-coccidial properties and mechanisms of an edible herb, Bidens pilosa, and its active compounds for coccidiosis. Sci Rep 2019; 9: 2896

[83] Laribi B, Kouki K, M’Hamdi M, Bettaieb T. Coriander (Coriandrum sativum L.) and its bioactive constituents. Fitoterapia 2015; 103: 9-26

[84] Thompson A, Meah D, Ahmed N, Conniff-Jenkins R, Chileshe E, Phillips CO, Claypole TC, Forman DW, Row PE. Comparison of the antibacterial activity of essential oils and extracts of medicinal and culinary herbs to investigate potential new treatments for irritable bowel syndrome. BMC Complement Altern Med 2013; 13: 338

[85] Silva F, Ferreira S, Queiroz JA, Domingues FC. Coriander (Coriandrum sativum L.) essential oil: its antibacterial activity and mode of action evaluated by flow cytometry. J Med Microbiol 2011; 60: 1479-1486

[86] Naderi Farsani M, Hoseinifar SH, Rashidian G, Ghafari Farsani H, Ashouri G, Van Doan H. Dietary effects of Coriandrum sativum extract on growth performance, physiological and innate immune responses and resistance of rainbow trout (Oncorhynchus mykiss) against Yersinia ruckeri. Fish Shellfish Immunol 2019; 91: 233-240

[87] Awad E, Austin B, Lyndon A. Effect of dietary supplements on digestive enzymes and growth performance of rainbow trout (Oncorhynchus mykiss, Walbaum). J Am Sci 2012; 8: 858-864

[88] Kot B, Wierzchowska K, Piechota M, Czerniewicz P, Chrzanowski G. Antimicrobial activity of five essential oils from Lamiaceae against multidrugresistant Staphylococcus aureus. Nat Prod Res 2019; 33: 3587-3591

[89] Horváth P, Koščová J. In vitro antibacterial activity of mentha essential oils against Staphylococcus aureus. Folia Vet 2017; 61: 71-77

[90] Miguel MG. Antioxidant and anti-inflammatory activities of essential oils: a short review. Molecules 2010; 15: 9252-9287

[91] Anwar F, Abbas A, Mehmood T, Gilani AH, Rehman NU. Mentha: A genus rich in vital nutra-pharmaceuticals-a review. Phytother Res 2019; 33: 2548-2570

[92] Lang M, Ferron PJ, Bursztyka J, Montjarret A, Duteil E, Bazire A, Bedoux G. Evaluation of immunomodulatory activities of essential oils by high content analysis. J Biotechnol 2019; 303: 65-71
[93] Didry N, Dubreuil L, Pinkas M. Antimicrobial activity of thymol, carvacrol and cinnamaldehyde alone or in combination. Pharmazie 1993; 48: 301-304

[94] Si W, Gong J, Tsao R, Zhou T, Yu H, Poppe C, Johnson R, Du Z. Antimicrobial activity of essential oils and structurally related synthetic food additives towards selected pathogenic and beneficial gut bacteria. J Appl Microbiol 2006; 100: 296-305

[95] Nowotarska SW, Nowotarski K, Grant IR, Elliott CT, Friedman M, Situ C. Mechanisms of antimicrobial action of cinnamon and oregano oils, cinnamaldehyde, carvacrol, 2,5-dihydroxybenzaldehyde, and 2-hydroxy5-methoxybenzaldehyde against Mycobacterium avium subsp. paratuberculosis (Map). Foods, 2017; 6: 72

[96] Major P, Revajová V, Levkut M, Ševčíková Z, Spišáková V, Faixová Z, Levkutová M, Kožárová I, Goldová M, Levkut M. Intestinal mucin dynamic and leukocytic responses of chickens infected with Eimeria acervulina and fed oregano supplemented diet. Acta Veterinaria Brno 2011; 80: 147-156

[97] Rostami F, Ghasemi HA, Taherpour K. Effect of Scrophularia striata and Ferulago angulata, as alternatives to virginiamycin, on growth performance, intestinal microbial population, immune response, and blood constituents of broiler chickens. Poult Sci 2015; 94: 2202-2209

[98] Mahboubi M, Kazempour N, Boland Nazar AR. Total phenolic, total flavonoids, antioxidant and antimicrobial activities of Scrophularia striata boiss extracts. Jundishapur ] Nat Pharm Prod 2013; 8: 15-19

[99] Monsef-Esfahani HR, Hajiaghaee R, Shahverdi AR, Khorramizadeh MR, Amini M. Flavonoids, cinnamic acid and phenyl propanoid from aerial parts of Scrophularia striata. Pharm Biol 2010; 48: 333-336

[100] Govahi R, Ghalamkari G, Toghyani M, Eghbalsaied S, Mohammadrezae M, Shahryari M, Abari AD. Effect of Ferulago angulata sub. carduchorum on total serum antioxidant activity and some of the humoral immune responses in broiler chicks. J Herbal Drug 2013; 4: 119-126

[101] Kovač J, Šimunović K, Wu Z, Klančnik A, Bucar F, Zhang Q, Možina SS. Antibiotic resistance modulation and modes of action of (-)-alphapinene in Campylobacter jejuni. PLoS One 2015; 10: e0122871

[102] Zhang HY, Piao XS, Zhang Q, Li P, Yi JQ, Liu JD, Li QY, Wang GQ. The effects of Forsythia suspensa extract and berberine on growth performance, immunity, antioxidant activities, and intestinal microbiota in broilers under high stocking density. Poult Sci 2013; 92: 1981-1988

[103] Wang Z, Xia Q, Liu X, Liu W, Huang W, Mei X, Luo J, Shan M, Lin R, Zou $D$, Ma Z. Phytochemistry, pharmacology, quality control and future research of Forsythia suspensa (Thunb.) Vahl: a review. J Ethnopharmacol 2018; 210: 318-339

[104] Sharifi SD, Khorsandi SH, Khadem AA, Salehi A, Moslehi H. The effect of four medicinal plants on the performance, blood biochemical traits and ileal microflora of broiler chicks. Vet Arh 2013; 83: 69-80

[105] Cross DE, McDevitt RM, Hillman K, Acamovic T. The effect of herbs and their associated essential oils on performance, dietary digestibility and gut microflora in chickens from 7 to 28 days of age. Br Poult Sci 2007; 48: 496-506

[106] Jimoh AA, Ibitoye EB, Dabai YU, Garba S. In vivo antimicrobial potentials of garlic against Clostridium perfringens and its promotant effects on performance of broiler chickens. Pak J Biol Sci 2013; 16: 1978-1984

[107] Ramiah SK, Zulkifli I, Rahim NA, Ebrahimi M, Meng GY. Effects of two herbal extracts and virginiamycin supplementation on growth performance, intestinal microflora population and fatty acid composition in broiler chickens. Asian-Australas J Anim Sci 2014; 27: 375-382

[108] Gracia MI, Millán C, Sánchez ], Guyard-Nicodème M, Mayot ], Carre Y, Csorbai A, Chemaly M, Medel P. Efficacy of feed additives against Campylobacter in live broilers during the entire rearing period: Part B. Poult Sci 2016; 95: 886-892

[109] Arczewska-Wlosek A, Swiatkiewicz S. Improved performance due to dietary supplementation with selected herbal extracts of broiler chickens infected with Eimeria spp. J Anim Feed Sci 2013; 22: 257-263 
[110] Waihenya RK, Mtambo MM, Nkwengulila G, Minga UM. Efficacy of crude extract of Aloe secundiflora against Salmonella gallinarum in experimentally infected free-range chickens in Tanzania. J Ethnopharmacol 2002; 79: 317-323

[111] Shokraneh M, Ghalamkari G, Toghyani M, Landy N. Influence of drinking water containing Aloe vera (Aloe barbadensis Miller) gel on growth performance, intestinal microflora, and humoral immune responses of broilers. Veterinary World 2016; 9: 1197-1203

[112] Akhtar M, Hai A, Awais MM, Iqbal Z, Muhammad F, ul Haq A, Anwar MI. Immunostimulatory and protective effects of Aloe vera against coccidiosis in industrial broiler chickens. Vet Parasitol 2012; 186: 170-177

[113] Youn HJ, Noh JW. Screening of the anticoccidial effects of herb extracts against Eimeria tenella. Vet Parasitol 2001; 96: 257-263

[114] Khalaji S, Zaghari M, Hatami K, Hedari-Dastjerdi S, Lotfi L, Nazarian H. Black cumin seeds, Artemisia leaves (Artemisia sieberi), and Camellia L. plant extract as phytogenic products in broiler diets and their effects on performance, blood constituents, immunity, and cecal microbial population. Poult Sci 2011; 90: 2500-2510

[115] Kaboutari J, Arab HA, Ebrahimi K, Rahbari S. Prophylactic and therapeutic effects of a novel granulated formulation of Artemisia extract on broiler coccidiosis. Trop Anim Health Prod 2014; 46: 43-48

[116] Pirali Kheirabadi K, Kaboutari Katadj J, Bahadoran S, Teixeira da Silva JA, Dehghani Samani A, Cheraghchi Bashi M. Comparison of the anticoccidial effect of granulated extract of Artemisia sieberi with monensin in experimental coccidiosis in broiler chickens. Exp Parasitol 2014; 141: 129-133

[117] Chang CL, Chung CY, Kuo CH, Kuo TF, Yang CW, Yang WC. Beneficial effect of Bidens pilosa on body weight gain, food conversion ratio, gut bacteria and coccidiosis in chickens. PLoS One 2016; 11: e0146141

[118] Yang WC, Tien Y], Chung CY, Chen YC, Chiou WH, Hsu SY, Liu HY, Liang $\mathrm{CL}$, Chang $\mathrm{CL}$. Effect of Bidens pilosa on infection and drug resistance of Eimeria in chickens. Res Vet Sci 2015; 98: 74-81

[119] Chang CL, Yang CY, Muthamilselvan T, Yang WC. Field trial of medicinal plant, Bidens pilosa, against eimeriosis in broilers. Sci Rep 2016; 6: 24692

[120] Lan L, Zuo B, Ding H, Huang Y, Chen X, Du A. Anticoccidial evaluation of a traditional Chinese medicine-Brucea javanica-in broilers. Poult Sci 2016; 95: 811-818

[121] Ahmad A, Abid H, Waheed S, Tarar OM, Zahra Y, Tehmina S, Ali TM. Effects of replacing antibiotic growth promoters (AGPS) with botanical extracts and oils in feed of laying hens on production, performance and some microbial counts in feces. J Anim Plant Sci 2016; 26: 893900

[122] Chowdhury S, Mandal GP, Patra AK, Kumar P, Samanta I, Pradhan S, Samanta AK. Different essential oils in diets of broiler chickens: 2 . Gut microbes and morphology, immune response, and some blood profile and antioxidant enzymes. Anim Feed Sci Technol 2018; 236: 39-47

[123] Tabatabaei SM, Badalzadeh R, Mohammadnezhad GR, Balaei R. Effects of cinnamon extract on biochemical enzymes, TNF-alpha and NF-kappa $B$ gene expression levels in liver of broiler chickens inoculated with Escherichia coli. Pesqui Vet Bras 2015; 35: 781-787

[124] Hosseinzadeh H, Alaw Qotbi AA, Seidavi A, Norris D, Brown D. Effects of different levels of coriander (Coriandrum sativum) seed powder and extract on serum biochemical parameters, microbiota, and immunity in broiler chicks. ScientificWorldjournal 2014; 2014: 628979

[125] Ghazanfari S, Mohammadi Z, Moradi MA. Effects of coriander essential oil on the performance, blood characteristics, intestinal microbiota and histological of broilers. Braz J Poultry Sci 2015; 17: 419-426

[126] Ebrahimi H, Rahimi S, Khaki P, Grimes JL, Kathariou S. The effects of probiotics, organic acid, and a medicinal plant on the immune system and gastrointestinal microflora in broilers challenged with Campylobacter jejuni. Turkish J Vet Anim Sci 2016; 40: 329-336
[127] Orengo J, Buendía A], Ruiz-Ibáñez MR, Madrid J, Del Río L, CataláGregori P, García V, Hernández F. Evaluating the efficacy of cinnamaldehyde and Echinacea purpurea plant extract in broilers against Eimeria acervulina. Vet Parasitol 2012; 185: 158-163

[128] Peek HW, Halkes SB, Mes J], Landman W]. In vivo screening of four phytochemicals/extracts and a fungal immunomodulatory protein against an Eimeria acervulina infection in broilers. Vet Q 2013; 33: 132-138

[129] Hashemi SR, Zulkifli I, Davoodi H, Zunita Z, Ebrahimie M. Growth performance, intestinal microflora, plasma fatty acid profile in broiler chickens fed herbal plant (Euphorbia hirta) and mix of acidifiers. Anim Feed Sci Technol 2012; 178: 167-174

[130] Zulkifli I, Hashemi SR, Somchit MN, Zunita Z, Loh TC, Soleimani AF, Tang SC. Effects of Euphorbia hirta and virginiamycin supplementation to the diet on performance, digestibility, and intestinal microflora population in broiler chickens. Arch Geflügelk 2012; 76: 6-12

[131] Gonzalez-Gil F, Diaz-Sanchez S, Pendleton S, Andino A, Zhang N, Yard C, Crilly N, Harte F, Hanning I. Yerba mate enhances probiotic bacteria growth in vitro but as a feed additive does not reduce Salmonella Enteritidis colonization in vivo. Poult Sci 2014; 93: 434-440

[132] Vase-Khavari K, Mortezavi SH, Rasouli B, Khusro A, Salem AZM, Seidavi A. The effect of three tropical medicinal plants and superzist probiotic on growth performance, carcass characteristics, blood constitutes, immune response, and gut microflora of broiler. Trop Anim Health Prod 2019; 51: 33-42

[133] Cetin E, Yibar A, Yesilbag D, Cetin I, Cengiz SS. The effect of volatile oil mixtures on the performance and ilio-caecal microflora of broiler chickens. Br Poult Sci 2016; 57: 780-787

[134] Franciosini MP, Casagrande-Proietti P, Forte C, Beghelli D, Acuti G, Zanichelli D, dal Bosco A, Castellini C, Trabalza-Marinucci M. Effects of oregano (Origanum vulgare L.) and rosemary (Rosmarinus officinalis L.) aqueous extracts on broiler performance, immune function and intestinal microbial population. J Appl Anim Res 2016; 44: 474-479

[135] Mohiti-Asli M, Ghanaatparast-Rashti M. Comparing the effects of a combined phytogenic feed additive with an individual essential oil of oregano on intestinal morphology and microflora in broilers. J Appl Anim Res 2017; 46: 184-189

[136] Scocco P, Forte C, Franciosini MP, Mercati F, Casagrande-Proietti P Dall'Aglio C, Acuti G, Tardella FM, Trabalza-Marinucci M. Gut complex carbohydrates and intestinal microflora in broiler chickens fed with oregano (Origanum vulgare L.) aqueous extract and vitamin E. J Anim Physiol Anim Nutr (Berl) 2017; 101: 676-684

[137] Scheurer W, Spring P, Maertens L. Effect of 3 dietary phytogenic products on production performance and coccidiosis in challenged broiler chickens. J Appl Poul Res 2013; 22: 591-599

[138] Arshad N, Neubauer C, Hasnain S, Hess M. Peganum harmala can minimize Escherichia coli infection in poultry, but long-term feeding may induce side effects. Poult Sci 2008; 87: 240-249

[139] Tanweer A], Chand N, Saddique U, Bailey CA, Khan RU. Antiparasitic effect of wild rue (Peganum harmala L.) against experimentally induced coccidiosis in broiler chicks. Parasitol Res 2014; 113: 2951-2960

[140] El-Abasy M, Motobu M, Na KJ, Shimura K, Nakamura K, Koge K, Onodera T, Hirota Y. Protective effects of sugar cane extracts (SCE) on Eimeria tenella infection in chickens. J Vet Med Sci 2003; 65: 865871

[141] Awais MM, Akhtar M, Muhammad F, ul Haq A, Anwar MI. Immunotherapeutic effects of some sugar cane (Saccharum officinarum L.) extracts against coccidiosis in industrial broiler chickens. Exp Parasitol 2011; 128: $104-110$

[142] Piesova E, Makova Z, Levkut M, Faixova Z, Pistl ], Marcin A, Levkut M. The effects of sage extract feed supplementation on biochemical parameters, weight of internal organs and Salmonella counts in chickens. Res Vet Sci 2012; 93: 1307-1308

[143] Agostini PS, Solà-Oriol D, Nofrarías M, Barroeta AC, Gasa J, Manzanilla EG. Role of in-feed clove supplementation on growth performance, in- 
testinal microbiology, and morphology in broiler chicken. Livest Sci 2012; 147: 113-118

[144] Sadek KM, Ahmed HA, Ayoub M, Elsabagh M. Evaluation of Digestarom and thyme as phytogenic feed additives for broiler chickens. Europ Poult Sci 2014; 78: 12

[145] Grabensteiner E, Liebhart D, Arshad N, Hess M. Antiprotozoal activities determined in vitro and in vivo of certain plant extracts against Histomonas meleagridis, Tetratrichomonas gallinarum and Blastocystis sp. Parasitol Res 2008; 103: 1257-1264

[146] Wang ML, Suo X, Gu JH, Zhang WW, Fang Q, Wang X. Influence of grape seed proanthocyanidin extract in broiler chickens: effect on chicken coccidiosis and antioxidant status. Poult Sci 2008; 87: 2273 2280

[147] Altop A, Erener G, Duru ME, Isik K. Effects of essential oils from Liquidambar orientalis Mill. leaves on growth performance, carcass and some organ traits, some blood metabolites and intestinal microbiota in broilers. Br Poult Sci 2018; 59: 121-127

[148] López CAA, Lima KRS, Manno MC,. Tavares FB, Fernandes Neto DL, Jesus MLC, Viana MAO, Fonseca LAB. Effects of cashew nut shell liquid (CNSL) on the performance of broiler chickens. Arq Bras Med Vet Zootec 2012; 64: 1027-1035

[149] Wang D, Zhou L, Li W, Zhou H, Hou G. Anticoccidial effects of areca nut (Areca catechu L.) extract on broiler chicks experimentally infected with Eimeria tenella. Exp Parasitol 2018; 184: 16-21

[150] Nweze NE, Obiwulu IS. Anticoccidial effects of Ageratum conyzoides. J Ethnopharmacol 2009; 122: 6-9

[151] Ahad S, Tanveer S, Nawchoo IA, Malik TA. Anticoccidial activity of Artemisia vestita (Anthemideae, Asteraceae)-a traditional herb growing in the Western Himalayas, Kashmir, India. Microb Pathog 2017; 104: 289-295

[152] Michels MG, Bertolini LC, Esteves AF, Moreira P, Franca SC. Anticoccidial effects of coumestans from Eclipta alba for sustainable control of Eimeria tenella parasitosis in poultry production. Vet Parasitol 2011; 177: 55-60

[153] Bakari GG, Max RA, Mdegela RH, Phiri EC, Mtambo MM. Effect of resinous extract from Commiphora swynnertonii (Burrt) on experimental coccidial infection in chickens. Trop Anim Health Prod 2013; 45: 455459

[154] Ogbe AO, Atawodi SE, Abdu PA, Sannusi A, Itodo AE. Changes in weight gain, faecal oocyst count and packed cell volume of Eimeria tenella-infected broilers treated with a wild mushroom (Ganoderma lucidum) aqueous extract. J S Afr Vet Assoc 2009; 80: 97-102

[155] Zhang DF, Sun BB, Yue YY, Zhou QJ, Du AF. Anticoccidial activity of traditional Chinese herbal Dichroa febrifuga Lour. extract against Eimeria tenella infection in chickens. Parasitol Res 2012; 111: 2229-2233

[156] Ghazaghi M, Mehri M, Bagherzadeh-Kasmani F. Effects of dietary Mentha spicata on performance, blood metabolites, meat quality and microbial ecosystem of small intestine in growing Japanese quail. Anim Feed Sci Tech 2014; 194: 89-98
[157] Bozkurt M, Ege G, Aysul N, Akşit H, Tüzün AE, Küçükyılmaz K, Borum AE, Uygun M, Akşit D, Aypak S, Şimşek E, Seyrek K, Koçer B, Bintaş E, Orojpour A. Effect of anticoccidial monensin with oregano essential oil on broilers experimentally challenged with mixed Eimeria spp. Poult Sci 2016; 95: 1858-1868

[158] Kurekci C, Al Jassim R, Hassan E, Bishop-Hurley SL, Padmanabha J, McSweeney CS. Effects of feeding plant-derived agents on the colonization of Campylobacter jejuni in broiler chickens. Poult Sci 2014; 93: 2337-2346

[159] Guo FC, Kwakkel RP, Williams BA, Parmentier HK, Li WK, Yang ZQ, Verstegen MW. Effects of mushroom and herb polysaccharides on cellular and humoral immune responses of Eimeria tenella-infected chickens. Poult Sci 2004; 83: 1124-1132

[160] Rubio LA, Brenes A, Setién I, de la Asunción G, Durán N, Cutuli MT. Lactobacilli counts in crop, ileum and caecum of growing broiler chickens fed on practical diets containing whole or dehulled sweet lupin (Lupinus angustifolius) seed meal. Br Poult Sci 1998; 39: 354-359

[161] Ahad S, Tanveer S, Malik TA, Nawchoo IA. Anticoccidial activity of fruit peel of Punica granatum L. Microb Pathog 2018; 116: 78-83

[162] Lengsfeld C, Faller G, Hensel A. Okra polysaccharides inhibit adhesion of Campylobacter jejuni to mucosa isolated from poultry in vitro but not in vivo. Anim Feed Sci Technol 2007; 35: 113-125

[163] Ola-Fadunsin SD, Ademola IO. Direct effects of Moringa oleifera Lam (Moringaceae) acetone leaf extract on broiler chickens naturally infected with Eimeria species. Trop Anim Health Prod 2013; 46: 14231428

[164] Anosa GN, Okoro O]. Anticoccidial activity of the methanolic extract of Musa paradisiaca root in chickens. Trop Anim Health Prod 2011; 43: 245-248

[165] Papazahariadou M, Papadopoulos E, Christaki E, Georgopoulou I, Florou-Paneri P, Tserveni-Goussi A, Yannakopoulos A. Use of Fraxinus ornus as an alternative anti-coccidian in broilers experimentally infected with Eimeria tenella. Rev Med Vet (Toulouse) 2010; 161: 326331

[166] Wang D, Zhou L, Li W, Zhou H, Hou G. Anticoccidial effect of Piper sarmentosum extracts in experimental coccidiosis in broiler chickens. Trop Anim Health Prod 2016; 48: 1071-1078

[167] Retnani Y, Dan TM, Taryati. Morinda citrifolia L. leaf extract as antibacterial Salmonella typhimurium to increase productivity of quail (Coturnix coturnix japonica). Pak J Biol Sci 2014; 17: 560-564

[168] Erhan MK, Bolukbasi SC. Citrus peel oils supplementation in broiler diet: effects on performance, jejunum microflora and jejunum morphology. Braz J Poultry Sci 2017; 19: 15-21

[169] Charal JW, Bidner TD, Southern LL, Janes ME, Gutierrez ME, Lavergne TA. Anise oil dosage and its effect on growth performance and jejunal lesions during a Clostridium perfringens challenge in battery trials, and growth performance in a floor pen trial. J Appl Poult Res 2017; 26: 240-252 